University of Nebraska - Lincoln

DigitalCommons@University of Nebraska - Lincoln

2005

\title{
Alunite and the role of magmatic fluids in the Tambo high- sulfidation deposit, El Indio-Pascua belt, Chile
}

\author{
C.L. Deyell \\ University of British Columbia \\ R.O. Rye \\ U.S. Geological Survey \\ G.P. Landis \\ U.S. Geological Survey \\ T. Bissig \\ Queen's University, Kingston, Ontario, Canada
}

Follow this and additional works at: https://digitalcommons.unl.edu/usgsrye

Part of the Geochemistry Commons

Deyell, C.L.; Rye, R.O.; Landis, G.P.; and Bissig, T., "Alunite and the role of magmatic fluids in the Tambo high-sulfidation deposit, El Indio-Pascua belt, Chile" (2005). Geochemistry of Sulfate Minerals: A Tribute to Robert O. Rye. 4.

https://digitalcommons.unl.edu/usgsrye/4

This Article is brought to you for free and open access by the US Geological Survey at DigitalCommons@University of Nebraska - Lincoln. It has been accepted for inclusion in Geochemistry of Sulfate Minerals: A Tribute to Robert O. Rye by an authorized administrator of DigitalCommons@University of Nebraska - Lincoln. 


\title{
Alunite and the role of magmatic fluids in the Tambo high-sulfidation deposit, El Indio-Pascua belt, Chile
}

\author{
C.L. Deyell ${ }^{\mathrm{a}, *}$, R.O. Rye ${ }^{\mathrm{b}}$, G.P. Landis ${ }^{\mathrm{b}}$, T. Bissig ${ }^{\mathrm{c}}$ \\ ${ }^{a}$ Mineral Deposit Research Unit, Department of Earth and Ocean Sciences, University of British Columbia, 6339 Stores Rd., \\ Vancouver, Canada V6T $1 Z 4$ \\ ${ }^{\mathrm{b}}$ U.S. Geological Survey, MS-963 Denver Federal Center, Denver, CO, 80225, USA \\ ${ }^{\mathrm{c}}$ Department of Geological Sciences and Geological Engineering, Queen's University, Kingston, Ontario, Canada K7L $3 N 6$
}

Accepted 1 June 2004

\begin{abstract}
The Tambo high-sulfidation deposit, located within the El Indio-Pascua belt in Chile, produced almost $25 \mathrm{t}(0.8 \mathrm{M} \mathrm{oz})$ of gold from altered Tertiary rhyodacitic volcanic rocks. Episodic magmatic-hydrothermal activity in the district occurred over at least $4 \mathrm{my}$ and is characterized by several stages of acid-sulfate alteration, including magmatic-hydrothermal, magmatic steam, steam-heated, and apparent supergene assemblages. Two stages of $\mathrm{Au} \pm \mathrm{Ag}$ mineralization are recognized and are hosted in barite and alunite within hydrothermal breccias and veins. Isotopic compositions of fluid in alunite show a dominant magmatic signature, with only a variable ${ }^{18} \mathrm{O}$-enriched meteoric water component throughout the entire hydrothermal process. Alunite ${ }^{40} \mathrm{Ar} /{ }^{39} \mathrm{Ar}$ ages constrain the timing of alteration and the duration of the hydrothermal system. Pre-ore alteration occurred at about 10 to $11 \mathrm{Ma}$ and was contemporaneous with the volcanism of the Tambo Formation. Alunite from this stage of alteration occurs in the matrix of barren breccias and as fine intergrowths of alunite-quartz \pm clays that selectively replaced feldspars and pumice fragments. The textural relationships combined with stable-isotope systematics suggest a magmatic-hydrothermal origin for the alunite, with a local magmatic steam overprint. Early ore-stage alunite $(8.7 \pm 0.2 \mathrm{Ma})$ occurs with barite and gold \pm walthierite within open spaces of the breccia matrix, and has $\delta^{34} \mathrm{~S}$ values (24-27\%o) typical of magmatic-hydrothermal alunite, reflecting equilibrium between aqueous $\mathrm{H}_{2} \mathrm{~S}$ and $\mathrm{SO}_{4}^{2-}$. Fluid-inclusion ratios of $\mathrm{H}_{2} \mathrm{~S}_{2} \mathrm{SO}_{2}$ (approximately 6) are consistent with ratios determined from stable-isotope data, and indicate reduced fluid conditions during ore deposition. Vaporphase transport of $\mathrm{Au}$, and deposition from condensed magmatic vapor rising from the brittle-ductile transition is inferred. Late gold coprecipitated with a third stage of alunite $(8.2 \pm 0.2 \mathrm{Ma})$ that is characterized by nearly uniform chemical compositions and $\delta^{34} \mathrm{~S}$ values $\left(1 \%\right.$ ) similar to those for associated enargite, reflecting disequilibrium between $\mathrm{H}_{2} \mathrm{~S}$ and $\mathrm{SO}_{4}^{2-}$. This third-stage of alunite is isotopically and chemically similar to that of post-ore, coarse, banded alunite \pm hematite-quartz veins that crosscut the breccias in the Tambo area. Analyses of fluid-inclusion gas from alunite in these veins indicate high $\mathrm{SO}_{2}$ and disequilibrium $\mathrm{CO}_{2}-\mathrm{CO}-\mathrm{CH}_{4}-\mathrm{H}_{2}$ species, consistent with a magmatic-steam origin. The gases are also depleted in $\mathrm{He}$, and the late goldbearing alunite was probably precipitated from rapidly ascending $\mathrm{SO}_{2}$-rich vapors that were flashed from condensed magmatic
\end{abstract}

\footnotetext{
* Corresponding author. Present address: Centre for Ore Deposit Research, University of Tasmania, Private Bag 79, Hobart, Tasmania, 7001, Australia. Tel.: +6136226 1735; fax: +61362267662 .

E-mail address: cdeyell@utas.edu.au (C.L. Deyell).
}

0009-2541/\$ - see front matter (C) 2004 Elsevier B.V. All rights reserved. doi:10.1016/j.chemgeo.2004.06.038

This article is a U.S. government work, and is not subject to copyright in the United States. 
fluids located below the brittle-ductile transition. Alunite-huangite veins $(8.6 \pm 0.4 \mathrm{Ma})$ were formed intermediate to the two mineralizing events. Steam-heated alunite $(8.9 \pm 0.4 \mathrm{Ma})$, derived from the oxidation of $\mathrm{H}_{2} \mathrm{~S}$ within the vadose zone, is preserved at the highest elevations and overlaps with Stage 2 ore deposition. Post-mineral alunite \pm jarosite $(7.3 \pm 0.1 \mathrm{Ma})$ occurs as apparent supergene crosscutting veins and overgrowths. Stable-isotope data, however, indicate a strong magmatic component to both near-surface and late-stage alunite-forming fluids. This dominant magmatic fluid signature at high levels during the waning stages of hydrothermal activity is attributed to climatic and physiographic conditions specific to the El Indio-Pascua belt during the Middle to Late Miocene.

(c) 2004 Elsevier B.V. All rights reserved.

Keywords: Alunite; El Indio-Pascua belt; Tambo deposit; Acid-sulfate; Stable isotopes; Epithermal; Gold

\section{Introduction}

The Tambo high-sulfidation gold deposit is located in the El Indio-Pascua belt, within the Main Cordillera of Chile (Fig. 1). This belt hosts widespread zones of acid-sulfate hydrothermal alteration and several world-class epithermal deposits and prospects, including the El Indio mine ( $>15$ t gold produced; Heather, personal communication, 2001), Pascua-Lama, with proven and probable resources of about $530 \mathrm{t}(17 \mathrm{M}$ oz) gold, and Veladero, with $317 \mathrm{t}(11 \mathrm{M} \mathrm{oz})$ gold (data from Barrick Gold Corporation website, 2003). The Tambo deposit is relatively small in comparison, and produced a total of just over $24.8 \mathrm{t}(0.8 \mathrm{M} \mathrm{oz})$ of gold from several tectonic-hydrothermal breccias and high-grade veins while it was in operation.

Previous studies of the El Indio district (Siddeley and Areneda, 1985; Bennet, 1995; Jannas, 1995; Jannas et al., 1999) have constrained the geological setting of the Tambo deposit. This region has many features in common with other high-sulfidation systems, although the deposit is unique in several aspects.

(1) Limited erosion has allowed the preservation of many features of the hydrothermal system, including the near-paleosurface. As such, multiple stages of alunite $\left[\mathrm{KAl}_{3}\left(\mathrm{SO}_{4}\right)_{2}(\mathrm{OH})_{6}\right]$ and acid-sulfate alteration can be recognized over several hundred meters of vertical extent. These stages include each of the four major types of acid-sulfate alteration described by Rye et al. (1992): magmatic-hydrothermal, magmaticsteam, steam-heated, and apparent supergene.

(2) Mineralization is sulfide- and $\mathrm{Cu}$-poor in comparison to that in most other deposits of this type (e.g., Cooke and Simmons, 2000;
Sillitoe, 1999). Ore is hosted primarily in barite and alunite \pm quartz of magmatic-hydrothermal origin. A second stage of $\mathrm{Au}$ mineralization is hosted in, and associated with, alunite of magmatic-steam origin (this study; Jannas et al., 1999).

In this paper, we examine shallow-level magmatichydrothermal processes within a well-constrained geological framework. The goal was to clarify the evolution of the Tambo deposit and, in particular, to determine the role of magmatic fluids throughout the life of the hydrothermal system, the mechanisms of ore-metal transport, and the nature of magmatic-steam processes. Emphasis is placed on the temporal and spatial relationship between alunite and $\mathrm{Au}$ mineralization because the isotopic, geochronological, and geochemical characteristics of alunite can be used to resolve the nature of source fluids (e.g., Bethke, 1984; Rye et al., 1992). Multiple stages of alunite have been recognized at the Tambo deposit. The relative timing of major alteration and mineralizing events was determined from the paragenetic sequence defined by Jannas (1995), with additional constraints from field relations and new ${ }^{40} \mathrm{Ar} /{ }^{39} \mathrm{Ar}$ ages for alunite.

\section{Geological framework}

\subsection{Regional geology}

The El Indio-Pascua belt is in the center of a presently amagmatic segment of the Andean Cordillera. The lack of recent volcanism is attributed to subhorizontal subduction of the Nazca plate beneath the South American continent between $27^{\circ} 30^{\prime}$ and 


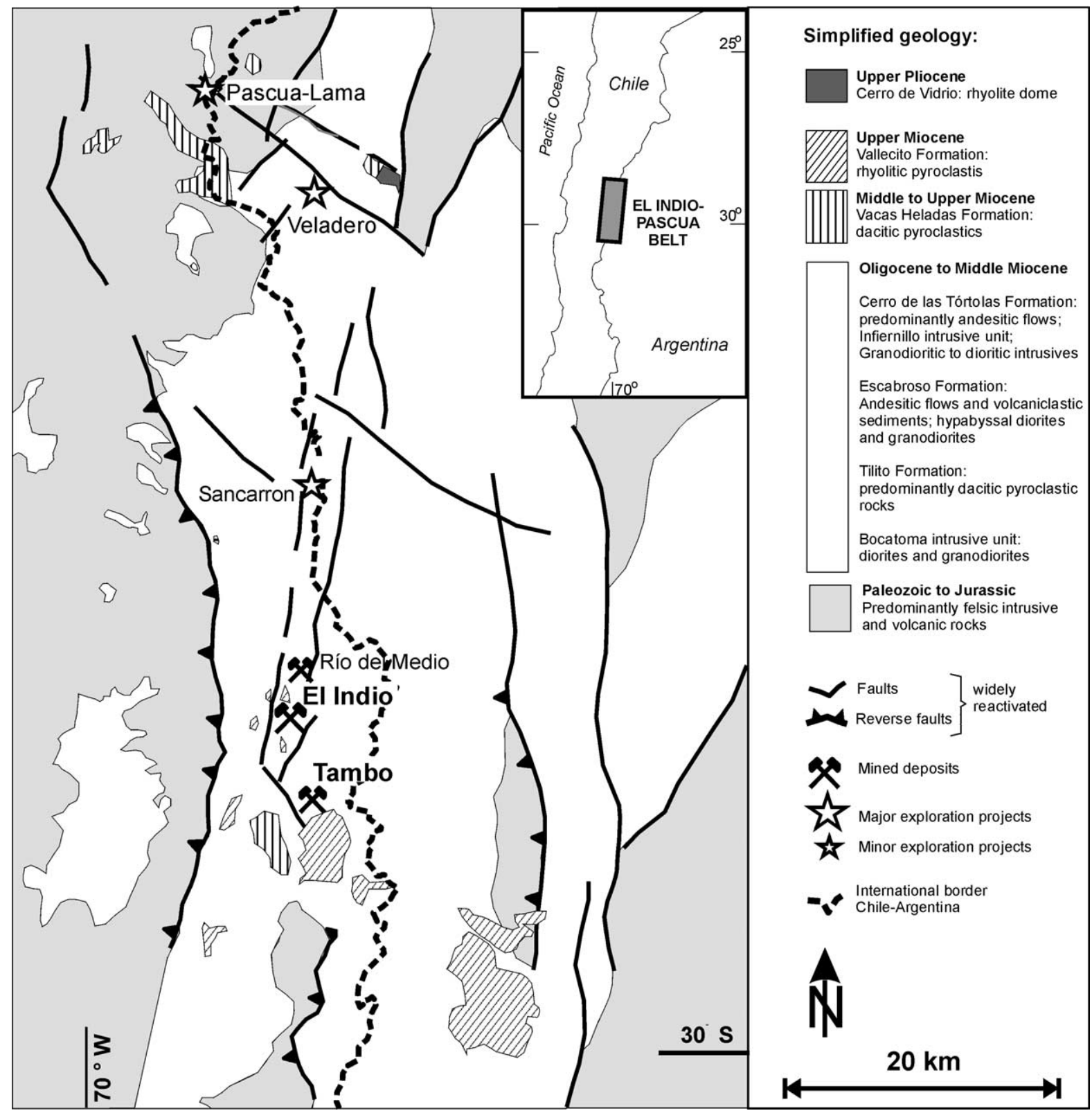

Fig. 1. Simplified geology of the El Indio-Pascua belt, showing the locations of the Tambo and El Indio deposits.

$33^{\circ} \mathrm{S}$ (Barazangi and Isacks, 1976). The district is approximately $100 \mathrm{~km}$ long and 30-40 km wide, and straddles the Chile-Argentina border (Fig. 1). Hydrothermal systems formed within a NNE-striking tectonic depression bounded by the steeply westdipping high-angle reverse Baños del Toro Fault to the west and opposing structures in the Valle del
Cura region of Argentina to the east. Within this block, an Upper Paleozoic to lower Jurassic basement consisting predominantly of calc-alkaline felsic intrusive suites and volcanic-sedimentary rocks (Martin et al., 1999) is overlain by up to $1500 \mathrm{~m}$ of Tertiary subaerial volcano-sedimentary strata. The latter are extensively preserved in the southern part 
of the belt, where the Tambo and El Indio mines are located (Fig. 1), but are less extensive in the northern extremity of the district near Pascua-Lama and Veladero (Maksaev et al., 1984; Martin et al., 1995).

The Tertiary volcanic sequence is briefly summarized here (Martin et al., 1995; Bissig, 2001). Up to 1200 $\mathrm{m}$ of dacitic and rhyodacitic tuffs with volcaniclastic sediments and subordinate basaltic and andesitic flows comprise the 23-27-Ma Tilito Formation. It is separated from the overlying 17.5-21-Ma Escabroso Formation by an angular unconformity marked by a locally well-developed regolith (Heather, personal communication, 2001). The Escabroso Formation consists predominantly of andesitic lavas, hypabyssal intrusive bodies, and volcaniclastic sedimentary rocks. After a brief deformation event, igneous activity resumed and is represented by the 14-17-Ma andesitic Cerro de las Tórtolas Formation and the contemporaneous Infiernillo intrusive unit. Dacitic pyroclastic rocks of the Tambo Formation (formerly the Vacas Heladas Formation; Martin et al., 1997) erupted from isolated centers between 11 and $12.7 \mathrm{Ma}$. A single 7.8Ma dacite dike, the only igneous rock coeval with mineralization in the district, has been reported to occur at Pascua (Bissig, 2001). The 5.5-6.2-Ma Vallecito Formation rhyolitic tuffs are restricted to an ignimbrite

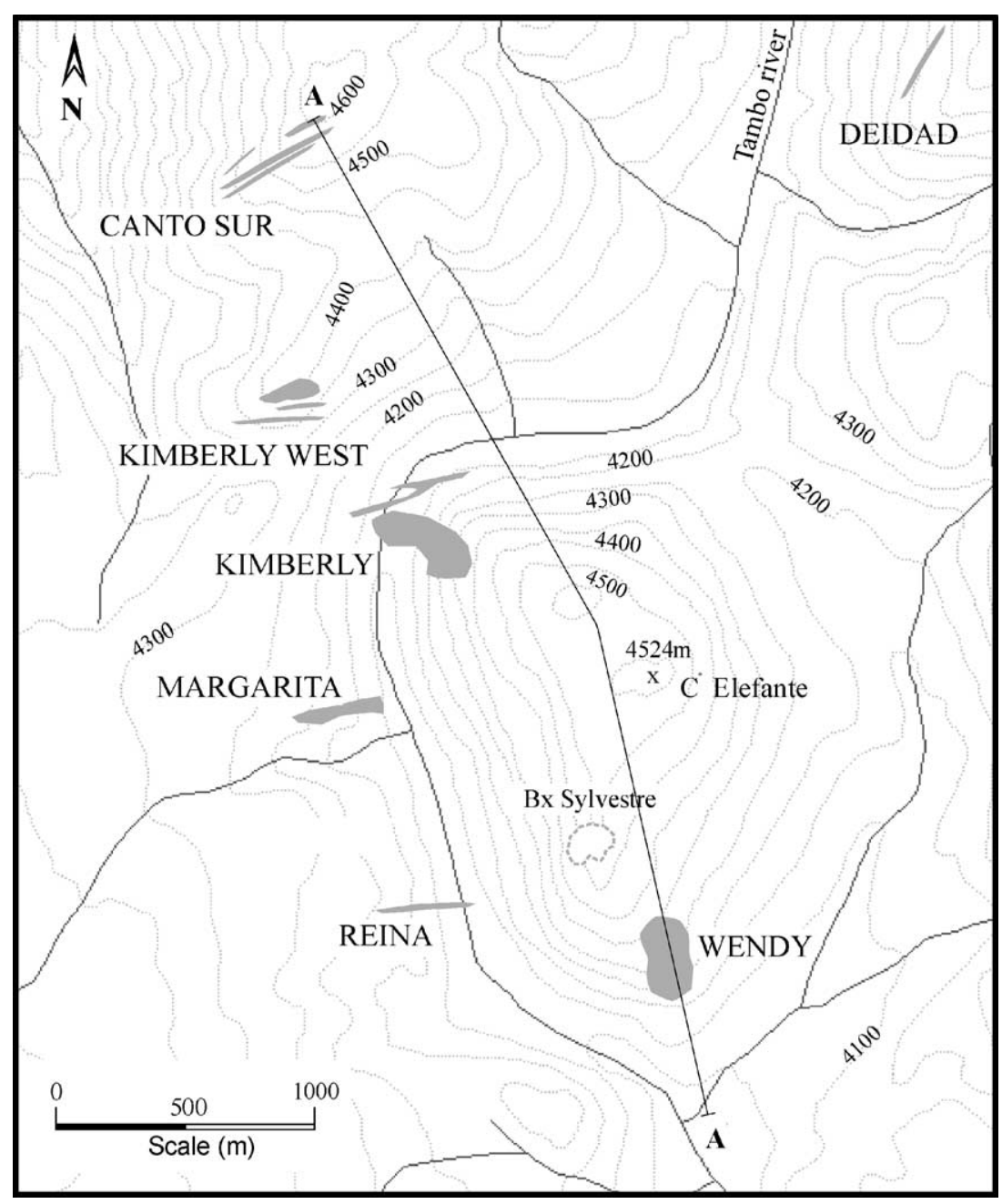

Fig. 2. Map of the Tambo property (modified from Jannas et al., 1999). Shaded areas indicate zones of mineralization. 
sheet in the Valle del Cura (Ramos et al., 1989) and other, isolated occurrences in the El Indio-Tambo area. Volcanism ceased in the Upper Pliocene after eruption of the 2-Ma Cerro de Vidrio rhyolite dome in the northeastern corner of the belt (Bissig, 2001).

\subsection{Local geology and mineralization}

The geology of the El Indio-Tambo area is dominated by an upper Oligocene to Upper Miocene sequence of intensely fractured volcanic and volcaniclastic rocks. The epithermal mineralization is hosted by rhyolitic to dacitic, lithic ash-flow tuffs of the Tilito Formation (Heather and Diaz, 2000; Bissig, 2001) and, at El Indio, is overlain by andesitic lavas of the Escabroso Formation. Intrusive units and hydrothermal alteration of Escabroso and Infiernillo age are also present in the area, but ${ }^{40} \mathrm{Ar} /{ }^{39} \mathrm{Ar}$ ages for gold mineralization both at $\mathrm{El}$ Indio and Tambo are significantly younger than these intrusions (Bissig, 2001).

Gold (and Ag) mineralization at Tambo is hosted in three major hydrothermal breccias and several highgrade veins. The geology of this deposit is summarized after Siddeley and Areneda (1985) and Jannas et al. (1999). Two of the major breccia deposits, Kimberly and Wendy, are on the northwest and south flanks of Cerro Elefante, respectively (Figs. 2 and 3). These deposits have lateral and vertical dimensions of up to 300 and $400 \mathrm{~m}$, respectively, and consist of matrix-supported, monolithic breccias that contain altered fragments of volcanic tuffs (Jannas et al., 1999). The main ore zone occurs between 4200 and $4000 \mathrm{~m}$ a.s.l. (all elevations are reported as elevation above sea level) with grades up to $4-10 \mathrm{~g} \mathrm{t}^{-1} \mathrm{Au}$ and $10 \mathrm{~g} \mathrm{t}^{-1} \mathrm{Ag}$ (Jannas et al., 1999). The Canto Sur deposit is at a higher elevation on Cerro Canto, which separates the El Indio and Tambo mines. All three breccias are located at, or close to, the intersection of north-northwest and east-northeast fault systems in areas of intense shears and extensional joints (Jannas et al., 1999). Vein mineralization at Tambo is primarily hosted by the Reina, Deidad, and Indigena structures (Fig. 2). These veins are typically narrow (1-4 m wide), of limited vertical extent $(<200 \mathrm{~m})$, and consist primarily of barite and alunite \pm quartz. Ore grades averaged $15 \mathrm{~g} \mathrm{t}^{-1} \mathrm{Au}$ and $30 \mathrm{~g} \mathrm{t}^{-1} \mathrm{Ag}$, but locally exceeded $1000 \mathrm{~g} \mathrm{t}^{-1} \mathrm{Au}$ (Jannas et al., 1999).

Two stages of mineralization were recognized by Jannas et al. (1999). Early Au mineralization (Table 1) is closely associated with barite in both the veins and the breccia deposits. Gold and argentian gold, minor sulfides (including enargite, galena, and pyrite), and native tellurium and other Te minerals are concentrated along growth planes in the barite. Trace amounts of sulfides and gold occur interstitial to alunite overgrowths on barite grains. Gold also occurs locally on the rims of the breccia fragments. The second stage of mineralization is characterized by native gold that occurs in fractures and vugs, and interstitial to grains of alunite, hematite, jarosite, and barite. Inclusions of

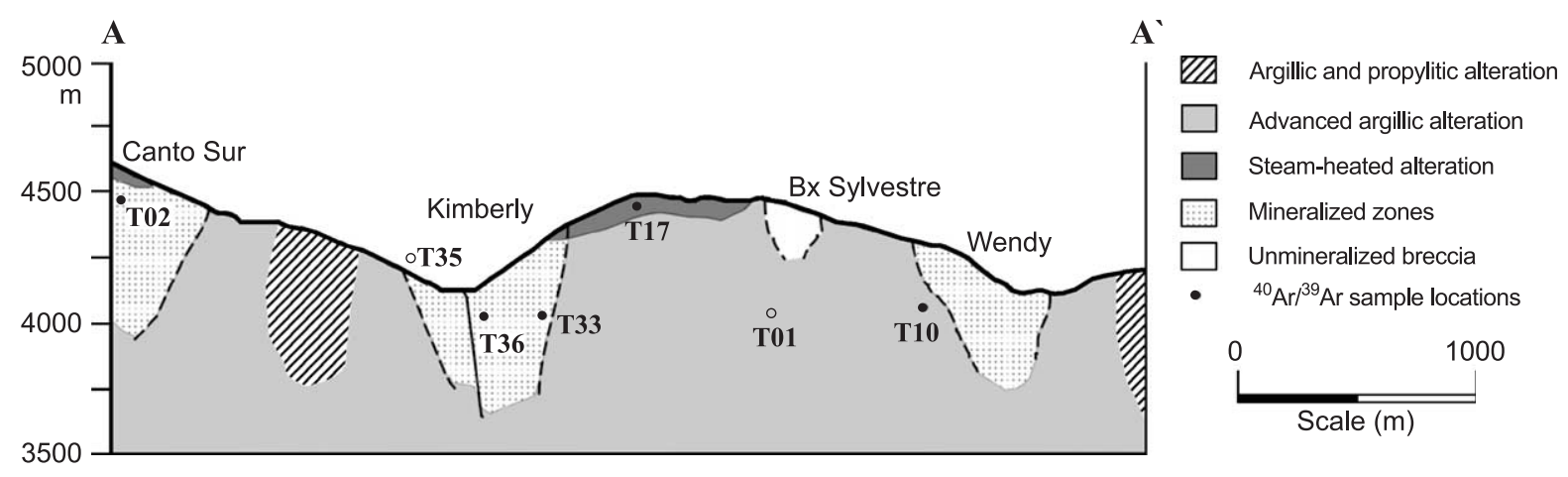

Fig. 3. Schematic section showing a projection of the three major mineralized breccias (Canto Sur, Kimberly, and Wendy) and zones of alteration at Tambo. Line of section is marked in Fig. 2. Also shown are locations of ${ }^{40} \mathrm{Ar}{ }^{39} \mathrm{Ar}$ samples; open symbols indicate samples projected onto the section. 
Table 1

Paragenetic sequence and characteristics of the eight different stages of alunite formation at Tambo ${ }^{\mathrm{a}}$

\begin{tabular}{|c|c|c|c|c|c|c|c|c|}
\hline & $\begin{array}{l}\text { Brecha } \\
\text { Sylvestre }\end{array}$ & Stage 1 & Stage 2 & Stage 3 & $\begin{array}{l}\text { Banded } \\
\text { veins }\end{array}$ & Steam-heated & $\begin{array}{l}\text { Huangite-bearing } \\
\text { veins }\end{array}$ & $\begin{array}{l}\text { Late-stage } \\
\text { oxidation }\end{array}$ \\
\hline${ }^{40} \mathrm{Ar} /{ }^{39} \mathrm{Ar}$ age & $10.42 \pm 0.28$ & $11.00 \pm 0.27$ & $8.71 \pm 0.21$ & $8.24 \pm 0.15$ & - & $8.86 \pm 0.38$ & $8.63 \pm 0.41$ & $7.25 \pm 0.14$ \\
\hline $\begin{array}{l}\text { Alunite } \\
\text { occurrence }\end{array}$ & $\begin{array}{l}\text { Matrix fill; } \\
\text { with qtz } \\
\text { and late jar }\end{array}$ & $\begin{array}{l}\text { Qtz-alun } \pm \text { kao, } \\
\text { dick, pyl } \\
\text { alteration of } \\
\text { Amiga tuff }\end{array}$ & $\begin{array}{l}\text { Vein and bx } \\
\text { matrix alun } \\
\text { associated } \\
\text { with bar, wal, } \\
\text { trace qtz, and } \\
\text { late jar }\end{array}$ & $\begin{array}{l}\text { Fine-grained } \\
\text { to coarse, } \\
\text { breccia and } \\
\text { vein filling } \\
\text { alun }\end{array}$ & $\begin{array}{l}\text { Coarse, } \\
\text { banded } \\
\text { alun veins } \\
\text { with hem }\end{array}$ & $\begin{array}{l}\text { Surficial } \\
\text { qtz-kao- } \\
\text { sulfur } \pm \text { alun } \\
\text { alteration }\end{array}$ & $\begin{array}{l}\text { Fine-grained, } \\
\text { thin pink } \\
\text { alun-huag } \\
\text { veinlets with } \\
\text { trace kao }\end{array}$ & $\begin{array}{l}\text { Fine-grained } \\
\text { alun with } \\
\text { minor qtz; } \\
\text { late jar }\end{array}$ \\
\hline Mineralization & - & - & $\begin{array}{l}\text { Gold, minor } \\
\text { sulfides } \\
\text { (en, gn, py), } \\
\text { native Te, } \\
\text { Te-Au } \\
\text { minerals, } \\
\text { native gold }\end{array}$ & $\begin{array}{l}\text { Native gold, } \\
\text { trace en }\end{array}$ & - & - & - & - \\
\hline
\end{tabular}

Abbreviated mineral names; alunite (alun), quartz (qtz), kaolinite (kao), dickite (dick), pyrophyllite (pyl), walthierite (wal), jarosite (jar), enargite (en), galena (gn), pyrite (py), hematite (hem), huangite (huag). Reported ${ }^{40} \mathrm{Ar} /{ }^{39} \mathrm{Ar}$ ages in bold are from this study; other ages are reported in Bissig (2001).

${ }^{a}$ Based on the nomenclature of Jannas et al. (1999) with additions from this study.

native gold also occur in alunite. Sulfides are rare, although minor enargite occurs at depth in the Wendy breccia, intergrown with coarse grains of alunite. Early tellurides typically are replaced by minerals such as poughite, rodalquilarite, and tellurite (Jannas et al., 1999).

\section{Methods of analysis}

Alteration assemblages were identified by field observations and detailed petrography. At the time of this study, access was limited to surficial outcrops, open pits (Kimberly, Wendy, and Canto Sur), and drill core. The mineralogy and character of each paragenetic stage were determined by examination of thin and polished sections using standard optical methods and X-ray diffraction (XRD). In addition, short-wave infrared (SWIR) analyses were made in situ using a Portable Infrared Mineral Analyzer (PIMA), which is a field-portable spectrometer. Spectra were analyzed using PIMAView 3.0 software, and mineral identification was made by comparison to standards in the SPECMIN database (Thompson et al., 1999). Repre- sentative samples from each paragenetic stage were selected for isotopic and geochemical analyses.

Six alunite samples were dated by ${ }^{40} \mathrm{Ar} /{ }^{39} \mathrm{Ar}$ laser step-heating methods. All analyses were done with a Mass Analyzer Products MAP 216 mass spectrometer at the Queen's University ${ }^{40} \mathrm{Ar}-{ }^{39} \mathrm{Ar}$ laboratory. About $10 \mathrm{mg}$ of each sample was irradiated for 7.5 $\mathrm{h}$ at the McMaster University nuclear reactor in Hamilton, Canada, using biotite standard Mac-83 as a radiation-flux monitor $(24.36 \pm 0.17 \mathrm{Ma}$; Sandeman et al., 1999). $J$-values for individual samples were determined by second-order polynomial interpolation and, for the samples discussed in this article, were about $2.4 \times 10^{-3}$ and varied by less than $0.02 \times 10^{-3}$. Samples were step-heated using a defocused LEXEL $3500 \mathrm{Ar}$ laser-beam. Ages were calculated using the decay constants suggested by Steiger and Jäger (1977), and all errors are given at $2 \sigma$.

Geochemical characteristics of alunite were determined by analysis of individual grains and sample composites. Grain mounts and polished sections were analyzed by scanning electron microscopy with energy-dispersion spectroscopy (SEM-EDS) and electron-probe microanalysis (EPMA). EPMA data 
were collected on a fully automated CAMECA SX50 microprobe operated in the wavelength-dispersion mode and at $15 \mathrm{kV}$ excitation voltage, $10 \mathrm{nA}$ beam current, $15 \mu \mathrm{m}$ beam diameter, and total count time $<65$ s. Analytical parameters were chosen to minimize beam damage caused by the volatilization of alkali elements (Petersen and Thompson, 1992). Data reduction was done with the PAP method (Pouchou and Pichoir, 1985). Alunite separates ( $\sim 1 \mathrm{~g}$ samples) were carefully hand picked and treated using a 1:1 HF- $\mathrm{H}_{2} \mathrm{O}$ solution to remove silicate contaminants (Wasserman et al., 1992). The purity of separates was checked by XRD, and trace to minor amounts (i.e., $\leq 10$ vol.\%) of quartz, clays, or other impurities may have been present. Samples were analyzed by inductively coupled plasma mass spectrometry (ICP-MS) for trace-metal and rare-earthelement (REE) contents by ALS Chemex Laboratories, Canada. For trace-metal analysis, samples were dissolved in a mixture of $\mathrm{HClO}_{4}, \mathrm{HNO}_{3}$, and $\mathrm{HF}$ acids to ensure total dissolution. For REE determination, samples were fused with lithium metaborate prior to analysis. Data for REE in alunite are normalized to the average REE content of volcanic tuffs from the Tilito Formation (Bissig, unpublished data; average values given in Table 2) that host ore in the El Indio district.

Complete stable isotopic analyses $\left(\delta^{34} \mathrm{~S}, \delta \mathrm{D}\right.$, $\delta^{18} \mathrm{O}_{\mathrm{SO}_{4}}$, and $\left.\delta^{18} \mathrm{O}_{\mathrm{OH}}\right)$ were obtained for alunite from each paragenetic stage. Sulfur-isotope data

Table 2

Average major and REE geochemical data for unaltered rocks of the Tilito Fm $(n=3)$

\begin{tabular}{lrlr}
\hline & wt. $\%$ & & ppm \\
\hline $\mathrm{Na}_{2} \mathrm{O}$ & 2.89 & $\mathrm{La}$ & 31.6 \\
$\mathrm{~K}_{2} \mathrm{O}$ & 4.24 & $\mathrm{Ce}$ & 62.6 \\
$\mathrm{CaO}$ & 4.35 & $\mathrm{Pr}$ & 7.2 \\
$\mathrm{MgO}$ & 1.59 & $\mathrm{Nd}$ & 25.2 \\
$\mathrm{MnO}$ & 0.09 & $\mathrm{Sm}$ & 4.8 \\
$\mathrm{Fe}_{2} \mathrm{O}_{3}$ & 5.05 & $\mathrm{Eu}$ & 1.0 \\
$\mathrm{Al}_{2} \mathrm{O}_{3}$ & 16.39 & $\mathrm{Gd}$ & 3.9 \\
$\mathrm{P}_{2} \mathrm{O}_{5}$ & 0.16 & $\mathrm{~Tb}$ & 0.6 \\
$\mathrm{SiO}_{2}$ & 62.12 & $\mathrm{Dy}$ & 3.5 \\
$\mathrm{TiO}_{2}$ & 0.66 & $\mathrm{Ho}$ & 0.7 \\
$\mathrm{Total}$ & 97.54 & $\mathrm{Er}$ & 2.1 \\
& & $\mathrm{Tm}$ & 0.3 \\
& & $\mathrm{Yb}$ & 2.1 \\
& & $\mathrm{Lu}$ & 0.3 \\
\hline
\end{tabular}

Data from Bissig (2001); $\mathrm{Fe}_{2} \mathrm{O}_{3}$ from total Fe. REE by ICP-MS. were also obtained for selected samples of barite and enargite. All data were collected at the U.S. Geological Survey Isotope Laboratory in Denver, USA. Samples were separated and prepared according to the procedure of Wasserman et al. (1992). Sulfur isotopic ratios were determined by an on-line method using an elemental analyzer coupled to a Micromass Optima mass spectrometer (Gieseman et al., 1994). Analytical precision is better than $\pm 0.2 \%$. $\mathrm{D} / \mathrm{H}$ analyses were performed by a step-heated technique modified from Godfrey (1962), with analytical precision better than $\pm 3 \%$ (Wasserman et al., 1992). Oxygen-isotope data for alunite were collected for both sulfate and hydroxyl oxygen. For analysis of $\delta^{18} \mathrm{O}_{\mathrm{SO}_{4}}$, alunite was dissolved in a hot $\mathrm{NaOH}$ solution, and sulfate was precipitated as $\mathrm{BaSO}_{4}$ (Wasserman et al., 1992). The $\mathrm{BaSO}_{4}$ precipitate was then analyzed by fluorination with $\mathrm{BrF}_{5}$ at $580{ }^{\circ} \mathrm{C}$ in accordance with the standard analytical procedure of Clayton and Mayeda (1963), and as used by Pickthorn and O'Neil (1985). Analytical precision is estimated at $\pm 0.15 \%$ o. Values of $\delta^{18} \mathrm{O}_{\mathrm{OH}}$ were determined by material balance using the total-O isotopic composition of alunite (measured by fluorination with $\mathrm{BrF}_{5}$, described above) and the $\delta^{18} \mathrm{O}_{\mathrm{SO}_{4}}$ results. Several oxygenisotope analyses were also determined by pyrolysis with a Finnigan TC/EA coupled to a Finnigan Delta Plus XL mass spectrometer using continuous-flow methods modified from Kornexl et al. (1999). Analytical precision is better than $\pm 0.3 \%$ o.

Analyses of fluid-inclusion gas were done at the U.S. Geological Survey fluid-inclusion and noble-gas laboratories in Denver, USA. All samples were initially crushed in a sealed stainless steel tube to release gas from the inclusions. After analysis of this gas, the crushed alunite was heated at $200{ }^{\circ} \mathrm{C}$ for $1 \mathrm{~h}$ in the same tube to generate thermally released gas. The temperature chosen was sufficient to decrepitate fluid inclusions (especially vapor-rich inclusions) that still remained after crushing, yet avoided thermal decomposition of the alunite. The released gases from both extractions were split for gas-composition analysis on a calibrated quadrupole mass spectrometer (Pfeiffer Vacuum Prisma), and the remaining gas was analyzed for $\mathrm{He}$ and $\mathrm{Ne}$ isotopes on a high-resolution MAP 215-50 noble-gas instrument. Gas species were analyzed at approximately $10^{-8}$ Torr, with each 
analysis consisting of an average of 40 to 60 matrix calculations that correct for ion sensitivity and gas ionization fragmentation, and which calibrate the intensity response to standards. Results were determined as mol\% summed to $100 \%$ when normalized to nitrogen. The remaining gas was then processed to extract $\mathrm{He}$ and $\mathrm{Ne}$ by cryogenically removing other gases on charcoal, gettering the gas (Saes ST707), and concentrating the purified $\mathrm{He}$ and $\mathrm{Ne}$ in a smallvolume charcoal trap. Helium, and then $\mathrm{Ne}$, were separately analyzed by selective thermal desorption from the charcoal and expansion into the mass spectrometer. Helium and $\mathrm{Ne}$ calibration was achieved by processing laboratory air corrected for barometric pressure, temperature, and relative humidity using identical procedures $\left({ }^{4} \mathrm{He}=6.414 \mathrm{e}^{-12} \mathrm{~mol}\right.$ $\mathrm{V}^{-1} \pm 0.016 \%,{ }^{3} \mathrm{He}=9.951 \mathrm{e}^{-20} \mathrm{~mol} \mathrm{cps}{ }^{-1} \pm 0.144 \%$, ${ }^{3} \mathrm{He} /{ }^{4} \mathrm{He}$ detector discrimination $=1.03074 \pm 1.68 \%$; $\mathrm{Ne}$ isotopes are treated as normalized percentages and ratios only, but are corrected for ${ }^{40} \mathrm{Ar}^{+}$and $\mathrm{CO}_{2}^{+}$ isobaric interferences to ${ }^{20} \mathrm{Ne}$ and ${ }^{22} \mathrm{Ne}$ ).

\section{Alunite paragenesis in the Tambo system}

Multiple stages of alunite deposition are recognized in the Tambo district. The paragenetic sequence (Table 1) is adapted from Jannas et al. (1999) based on new field and petrographic observations, and reliable alunite ${ }^{40} \mathrm{Ar} /{ }^{39} \mathrm{Ar}$ ages from this study (see Section 5) and Bissig (2001). The different occurrences of alunite are described below.

\subsection{Brecha Sylvestre}

Brecha Sylvestre is a relatively small, barren breccia body at the southwestern end of Cerro Elefante (Fig. 2). The breccia occurs between 4430 and $4480 \mathrm{~m}$, approximately $200 \mathrm{~m}$ above the zones of highest gold production in the Wendy and Kimberly orebodies. The breccia is mainly clast-supported, locally silicified, and shows evidence of intense acid-leaching that removed most of the matrix material (Bennet, 1995). The matrix consists of alunite and minor quartz that line vugs (Fig. 4a). Alunite typically occurs as pale white to yellow, bladed to acicular crystals that are 20 to $200 \mathrm{im}$ in length. Late jarosite is also common and overgrows silicified breccia fragments and matrix crystals.

\subsection{Stage 1-pre-ore acid-sulfate alteration}

Widespread acid-sulfate alteration of the Tilito Formation wallrock is recognized throughout the Tambo area (Stage 1). This assemblage is surrounded by argillic- and propylitic-altered rocks away from the main orebodies (this study; Jannas, 1995). The occurrence of altered clasts with silicified rims in the hydrothermal breccias indicates that alteration occurred prior to brecciation and subsequent mineralization (Jannas et al., 1999). Alteration occurs as fine intergrowths of alunite-quartz that selectively replaced feldspar crystals and locally formed massive clusters in the matrix of the wallrock (Fig. 4b). Pumice clasts within fragments of dacite tuff in the breccia pipes are also replaced (Jannas, 1995). Original rock textures are generally preserved. Associated minerals include clays (kaolinite-dickite), pyrophyllite, rare pyrite, and diaspore. Alunite commonly occurs as clusters of tabular to bladed crystals between 50 ìm and $2 \mathrm{~mm}$ in length. Crystals locally have cores of aluminum-phospho-sulfate (APS) minerals, including woodhouseite, svanbergite, and florencite (Table 3). Alunite grains are also locally pitted, have corroded margins, and are rarely overprinted by fine-grained (10-20 ìm) alunite \pm quartz.

Fig. 4. (a) Medium-grained, tabular alunite crystals in the matrix of Brecha Sylvestre (crossed polars). Scale bar=50 $\mu \mathrm{m}$. (b) SEM backscatteredelectron (BSE) image of Stage 1 quartz (qtz)-alunite (aln) alteration. Bright zones within alunite grains are inclusions of woodhouseitesvanbergite. Scale bar=25 $\mu \mathrm{m}$. (c) BSE image of walthierite (light gray)-alunite (dark gray) zoning in Stage 2 alunite from the Canto Sur deposit. Alunite is hosted in barite (white). Scale bar $=50 \mu \mathrm{m}$. (d) BSE image of native gold (white) associated with Stage 2 alunite (gray) from Wendy (DDH-92a, $206.7 \mathrm{~m}$ ). Circle in centre of image is from electron-beam damage. Scale bar $=25 \mu \mathrm{m}$. (e) Fine-grained (white) Stage 3 alunite (alun) overgrown on coarser-grained Stage 3 alunite (gray) in the matrix of the Wendy breccia. Minor enargite (en) is associated with the coarsegrained alunite. Scale bar=1 cm. (f) Banded alunite-hematite vein from the Kimberly deposit. Scale bar=1 cm. (g) BSE image of zoned alunite (light gray)-huangite (darker gray)-woodhouseite-svanbergite (white) grains from the Kimberly pit. Scale bar=10 $\mu \mathrm{m}$. (h) BSE image of finegrained, fspseudocubic grains of alunite (gray) with minor jarosite (white). Scale bar=10 $\mu \mathrm{m}$. 

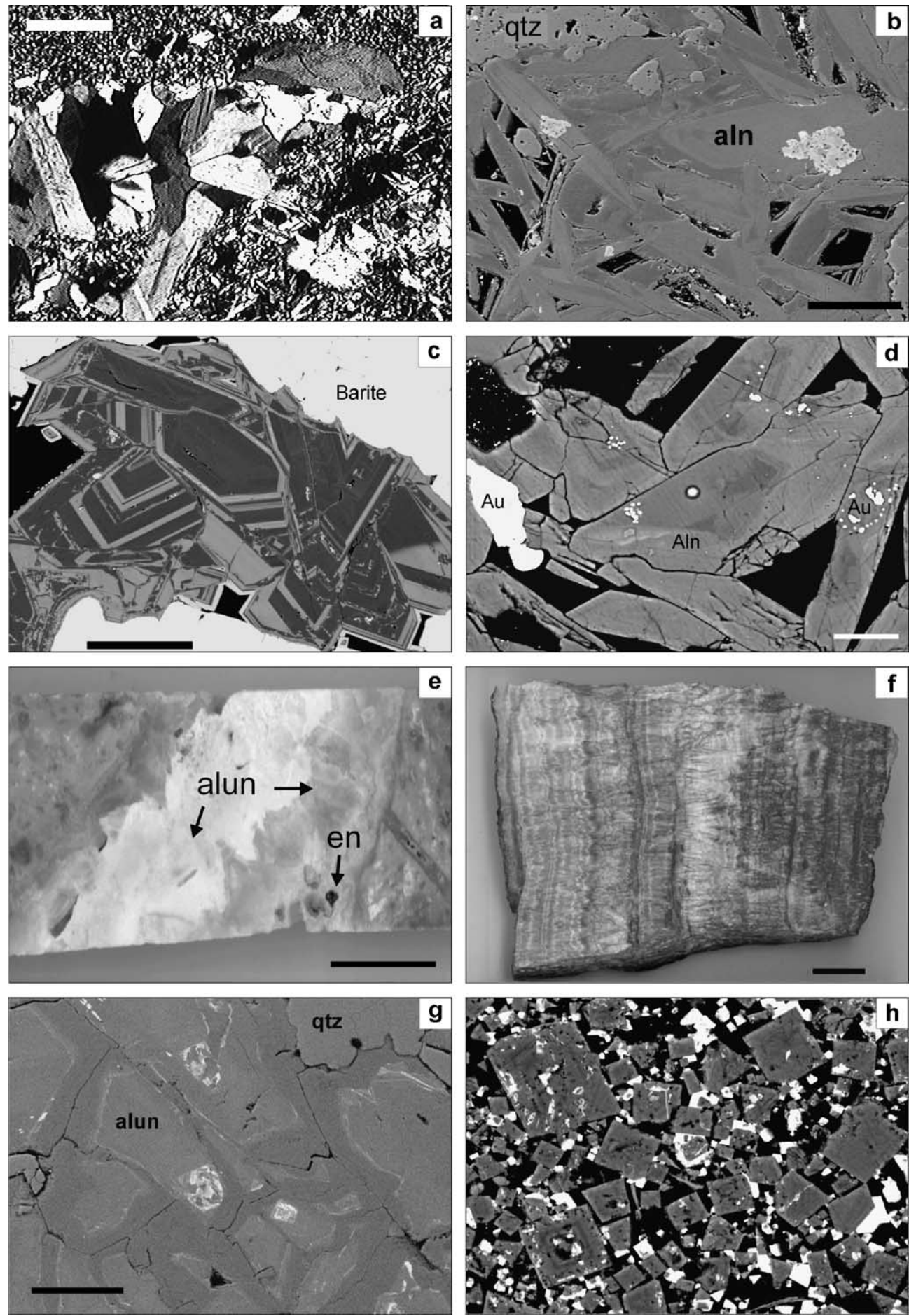
Table 3

Minerals of the alunite-jarosite family identified in the Tambo area

\begin{tabular}{|c|c|c|}
\hline $\begin{array}{l}\text { Alunite-jarosite } \\
\text { group }\end{array}$ & $\begin{array}{l}\text { alunite } \\
\text { natroalunite } \\
\text { minamiite } \\
\text { huangite } \\
\text { walthierite } \\
\text { jarosite }\end{array}$ & $\begin{array}{l}\mathrm{KAl}_{3}\left(\mathrm{SO}_{4}\right)_{2}(\mathrm{OH})_{6} \\
\mathrm{NaAl}_{3}\left(\mathrm{SO}_{4}\right)_{2}(\mathrm{OH})_{6} \\
(\mathrm{Na}, \mathrm{K}, \mathrm{Ca})_{2} \mathrm{Al}_{6}\left(\mathrm{SO}_{4}\right)_{4}\left(\mathrm{OH}, \mathrm{H}_{2} \mathrm{O}\right)_{12} \\
\mathrm{CaAl}_{6}\left(\mathrm{SO}_{4}\right)_{4}(\mathrm{OH})_{12} \\
\mathrm{BaAl}_{6}\left(\mathrm{SO}_{4}\right)_{4}(\mathrm{OH})_{12} \\
\mathrm{KFe}_{3}\left(\mathrm{SO}_{4}\right)_{2}(\mathrm{OH})_{6}\end{array}$ \\
\hline $\begin{array}{l}\text { Beudantite } \\
\text { group }\end{array}$ & $\begin{array}{l}\text { svanbergite } \\
\text { woodhouseite }\end{array}$ & $\begin{array}{l}\mathrm{SrAl}_{3}\left[(\mathrm{P}, \mathrm{S}) \mathrm{O}_{4}\right]_{2}\left(\mathrm{OH}, \mathrm{H}_{2} \mathrm{O}\right)_{6} \\
\mathrm{CaAl}_{3}\left[(\mathrm{P}, \mathrm{S}) \mathrm{O}_{4}\right]_{2}\left(\mathrm{OH}, \mathrm{H}_{2} \mathrm{O}\right)_{6}\end{array}$ \\
\hline $\begin{array}{l}\text { Crandallite } \\
\text { group }\end{array}$ & $\begin{array}{l}\text { crandallite } \\
\text { florencite-(Ce) } \\
\text { florencite-(La) }\end{array}$ & $\begin{array}{l}\mathrm{CaAl}_{3}\left(\mathrm{PO}_{4}\right)_{2}\left(\mathrm{OH}, \mathrm{H}_{2} \mathrm{O}\right)_{6} \\
\mathrm{CeAl}_{3}\left(\mathrm{PO}_{4}\right)_{2}\left(\mathrm{OH}, \mathrm{H}_{2} \mathrm{O}\right)_{6} \\
\mathrm{LaAl}_{3}\left(\mathrm{PO}_{4}\right)_{2}\left(\mathrm{OH}, \mathrm{H}_{2} \mathrm{O}\right)_{6}\end{array}$ \\
\hline
\end{tabular}

\subsection{Stage 2-early Au mineralization}

Stage 2 alunite post-dates the emplacement of the three major breccias and is closely associated with early deposition of Au (Jannas et al., 1999). Alunite typically occurs as euhedral, golden yellow, bladed crystals up to $1 \mathrm{~cm}$ long that have overgrown barite and breccia fragments. Finer-grained tabular crystals, $<50 \mu \mathrm{m}$ in length, also occur. Alunite of this stage is recognized by complex compositional zoning and the presence of walthierite (the $\mathrm{Ba}$ analogue of alunite; Table 3 ). The type of locality for walthierite is the Reina vein (Beane, 1991; Li et al., 1992), where the mineral forms irregular to oscillatory compositional zones (Fig. 4c) and aggregates in coarse-grained alunite crystals. Stage 2 alunite also occurs in the Kimberly and Canto Sur breccias in close association with barite and traces of quartz.

\subsection{Stage 3-late Au mineralization}

Deposition of Stage 3 alunite overlapped with the later stage of $\mathrm{Au}$ deposition and continued after mineralization ceased. Alunite is characterized by its nearly stoichiometric composition and variable crystal size and shape. Fine-grained alunite occurs as lath-like to thin bladed crystals, rarely $>30 \mu \mathrm{m}$ long, which form overgrowths on breccia fragments and Stage 2 barite crystals in the Kimberly and Canto Sur breccia pipes. Alunite commonly exhibits the characteristic 'earthy' texture described by Jannas et al. (1999) and locally contains inclusions of native gold (Fig. 4d). Coarser-grained varieties (up to $2 \mathrm{~cm}$ ) of white to pinkish brown, bladed alunite occur in veins, as cement to breccia fragments, as overgrowths on Stage 2 alunite crystals, and as local intergrowths with enargite (Fig. 4e). Fine-grained alunite crystals also post-date the coarser bladed veins and breccia matrix. Minor amounts of quartz and kaolinite are associated with this stage. Late jarosite and scorodite [FeAs $\mathrm{O}_{4} \cdot 2 \mathrm{H}_{2} \mathrm{O}$ ] that overprint Stage 3 alunite are common.

\subsection{Veins of coarse banded alunite ( \pm hematite)}

Veins, up to $20 \mathrm{~cm}$ wide, of coarsely crystalline alunite \pm hematite (Fig. 4f) are common in the upper and marginal parts of the Kimberly open pit, and occur locally in the Wendy breccia. The veins crosscut both Stage 1 alteration and hydrothermal breccias, but the timing of vein formation relative to Stage 3 alunite is unknown. The veins are characterized by coarse alunite crystals, 1 to $5 \mathrm{~mm}$ long, that grew in successive bands outward from the wallrock. Minor hematite and rare quartz \pm jarosite occur interstitial to the alunite crystals. The presence of hematite gives the veins a distinct reddish color that allows easy distinction from the surrounding wallrock. Where hematite is absent, the veins have a cream-white color.

\subsection{Huangite-bearing veins}

Another variety of late veins occurs in the Kimberly and Kimberly West open pits. These veinlets are thin, pink to white, cryptocrystalline, and are composed of alunite, huangite (the $\mathrm{Ca}$ analogue of alunite; Table 3) \pm kaolinite, quartz, and trace pyrite (Fig. 4g). Alunite occurs as clusters of tabular to anhedral grains averaging 50 to $100 \mu \mathrm{m}$ in length, locally overprinted by late jarosite and scorodite. The veinlets cut Stage 1 alteration, but timing with respect to Stage 2 or later events is unknown. Huangite had not been recognized previously in the Tambo area, but the type locality is in the El Indio district, where the mineral occurs in association with kaolinite and pyrite ( \pm alunite, pyrophyllite, sericite, minamiite, and woodhouseite) adjacent to the El Indio Campana B vein (Li et al., 1992). Alunite in this vein has been dated at $6.21 \pm 0.26 \mathrm{Ma}$ and represents the youngest alteration event in the district (Bissig, 2001).

\subsection{Near-surface alteration}

A powdery, friable assemblage of silica-kaolinite \pm alunite and native sulfur is present at higher elevations 
$(4300-4500 \mathrm{~m})$ in the Tambo district and occurs as alteration blankets on top of Cerro Elefante, Cerro Canto, and the adjacent Azufreras and Sol Poniente areas. Alteration is commonly pervasive, with the matrix of the host rocks and feldspars in tuff fragments completely replaced. Alteration also extends downward along fractures, particularly beneath the surficial alteration zone on Cerro Elefante, and locally overprints older acid-sulfate assemblages. Alunite in the near-surface zone is restricted to irregular pods and lenses and occurs as fine-grained $(<15-20 \mu \mathrm{m})$, tabular, and less commonly pseudocubic crystals intergrown with fine-grained silica. The mineralogy and distribution of this assemblage is typical of steam-heated alteration observed in geothermal fields (e.g., Schoen et al., 1974; Rye et al., 1992).

\subsection{Late alunite veins \pm jarosite}

Late, fine-grained to cryptocrystalline veinlets of alunite \pm jarosite are common in the Tambo area. These veinlets occur at all depths investigated by drilling (down to $3800 \mathrm{~m}$ elevation) and crosscut all other alteration types. The alunite is typically fine- to medium-grained $(10-50 \mu \mathrm{m})$, tabular to bladed in habit, and is locally intermixed with quartz. Alunite is commonly overgrown and locally crosscut by finegrained jarosite. In rare occurrences, extremely finegrained $(2-10 \mu \mathrm{m})$, pseudocubic alunite is intergrown with kaolinite \pm jarosite (Fig. 4h) in veinlets that crosscut wallrock altered by illite-smectite \pm chlorite. These late-stage veins were previously interpreted to be supergene in origin (Guerra, personal communication) on the basis of their distribution and field characteristics.

\section{Geochronology}

Six alunite samples were dated by the ${ }^{40} \mathrm{Ar} /{ }^{39} \mathrm{Ar}$ laser step-heating method to supplement existing age data for the Tambo area (Jannas et al., 1999; Bissig, 2001) and to confirm the relative timing of the alteration and mineralizing events. Results (Table 4) indicate that Stage 1 wallrock alteration $(11.0 \pm 0.3 \mathrm{Ma})$ occurred 2 to 3 my prior to either Stage 2 or Stage 3 ore deposition. Early alteration is contemporaneous with Tambo Formation volcanism, and extensive hydrothermal alteration of this age can be traced throughout the El Indio-Pascua belt (Bissig, 2001). A sample of coarse, vug-fill alunite from Brecha Sylvestre, dated at 10.4 $\pm 0.3 \mathrm{Ma}$ (Bissig, 2001), is also pre-ore and may overlap with Stage 1 alteration.

The timing of Stage 2 mineralization is constrained by ${ }^{40} \mathrm{Ar} /{ }^{39} \mathrm{Ar}$ data $(8.7 \pm 0.2 \mathrm{Ma})$ for a sample of coarse-grained alunite from the Reina vein that contains inclusions of gold. Alunite in this sample is also intergrown with barite that contains precious metals. Stage 3 mineralization is slightly younger according to data for medium-grained alunite $(8.2 \pm 0.2 \mathrm{Ma})$ sampled from the matrix of the Kimberly breccia.

The near-surface, blanket style of alteration $(8.9 \pm 0.4 \mathrm{Ma})$ was sampled at Cerro Elefante, above the Kimberly deposit. Alteration overlaps in time with Stage 2 and may represent the surficial (steamheated?) expression of early $\mathrm{Au}$ mineralization.

The timing of huangite-bearing veins $(8.6 \pm 0.4$ $\mathrm{Ma})$ relative to mineralization is uncertain. The relatively large error for this analysis is attributed to the small grain size of alunite and a smaller quantity of Ar gas released during heating. These veins may overlap with either Stage 2 or Stage 3, or may be

\begin{tabular}{|c|c|c|c|c|c|c|c|c|c|}
\hline Stage & Sample & Lab no. & $\begin{array}{l}\text { Integrated date } \\
(\mathrm{Ma} \pm 2 \sigma)\end{array}$ & $\begin{array}{l}\text { Plateau age } \\
(\mathrm{Ma} \pm 2 \sigma)\end{array}$ & $\begin{array}{l}\%^{39} \mathrm{Ar} \text { in } \\
\text { the plateau }\end{array}$ & $\begin{array}{l}\text { Correlation date } \\
(\mathrm{Ma} \pm 2 \sigma)\end{array}$ & $\begin{array}{l}{ }^{0}{ }^{39} \mathrm{Ar} \text { in } \\
\text { the correlation }\end{array}$ & MSWD & $\begin{array}{l}\text { Initial }{ }^{40} \mathrm{Ar} /{ }^{39} \mathrm{Ar} \\
( \pm 2 \sigma)\end{array}$ \\
\hline 1 & $\mathrm{~T} 10 \mathrm{a}$ & TB-106 & $10.87(0.34)$ & $11.00(0.27)$ & 94.4 & $11.10(1.46)$ & 100.0 & 0.16 & 291.17 (92.11) \\
\hline 2 & T01 & TB-110 & $8.71(0.21)$ & - & - & $8.72(0.63)$ & 100.0 & 0.43 & $290.79(166.77)$ \\
\hline Ca-vein & T35 & TB-103 & $8.61(0.45)$ & $8.63(0.41)$ & 87.2 & $6.97(6.28)$ & 100.0 & 3.70 & $526.85(1419.61)$ \\
\hline $\mathrm{SH}$ & $\mathrm{T} 17$ & TB-101 & $8.68(0.59)$ & $8.86(0.38)$ & 91.7 & $8.97(3.45)$ & 100.0 & 0.02 & $293.77(183.44)$ \\
\hline LV & T02a & TB-104 & $7.18(0.15)$ & $7.25(0.14)$ & 88.4 & $7.27(0.13)$ & 100.0 & 0.52 & $226.54(247.77)$ \\
\hline BV & $\mathrm{T} 33$ & TB-111 & $7.38(2.88)$ & $7.70(2.80)$ & 90.3 & $8.15(12.78)$ & 100.0 & 0.04 & $293.76(672.32)$ \\
\hline
\end{tabular}

Ca-vein=huangite-bearing vein, $\mathrm{SH}=$ steam-heated, $\mathrm{LV}=$ late vein, $\mathrm{BV}=$ banded vein. Calculated from data given in Deyell (2001). 
intermediate between the two. Crosscutting relations could not be determined in the field. It is clear, however, that alunite in these veins is unrelated to the much younger huangite-bearing Campana $\mathrm{B}$ vein at $\mathrm{El}$ Indio (6.2 $\pm 0.3 \mathrm{Ma}$; Bissig, 2001).

Late-stage alunite ( \pm jarosite) was sampled from thin veinlets that crosscut Stage 1 alteration in the Canto Sur deposit. The plateau age for this sample $(7.3 \pm 0.1 \mathrm{Ma})$ is approximately 1 my younger than the main mineralizing events in the Kimberly and Wendy areas. It should be noted, however, that Bissig (2001) reported an age of 7.1 $\pm 0.2 \mathrm{Ma}$ for alunite thought to be related to $\mathrm{Au}$ deposition in the Canto Sur breccia. The paragenesis of this sample is unclear. The style and mineralogy of both the alteration and the ore assemblages at Canto Sur are similar to those in other parts of the Tambo deposit. These features suggest a common origin. If mineralization in this area is younger, however, then latestage alteration is coeval with, and not younger than, Canto Sur ore-stage alunite.

Repeated attempts to obtain accurate age data for banded-vein alunite were unsuccessful because the samples failed to release sufficient Ar. The reported plateau age of $7.7 \pm 2.8 \mathrm{Ma}$ does not help constrain the timing of the banded veins relative to other stages of Tambo alteration and gold deposition.

\section{Stable-isotope study}

Stable-isotope analyses of alunite were determined for each paragenetic stage. Alunite contains four stable-isotope sites and $\delta^{34} \mathrm{~S}, \delta \mathrm{D}, \delta^{18} \mathrm{O}_{\mathrm{SO}_{4}}$, and $\delta^{18} \mathrm{O}_{\mathrm{OH}}$ data can be used to characterize the fluid source and environment of deposition for each stage of alteration (Rye et al., 1992). Brief sample descriptions and isotope results are presented in Table 5. The data show considerable variation in $\delta^{34} \mathrm{~S}$ of alunite, with values ranging from $0 \%$ to $27 \%$ (Fig. 5). Limited data for Stage 3 enargite range from about $-2 \%$ o to $-4 \%$, consistent with values reported in Jannas et al. (1999).

Estimation of $\delta^{34} \mathrm{~S}$ for bulk $\mathrm{S}$ in the magma (1$3 \%$; Fig. 5) is based on data for magmatic-steam alunite (cf. Rye et al., 1992) and agrees with estimates presented by Jannas et al. (1999). The $\delta \mathrm{D}$ of ambient meteoric waters is estimated at $-100 \pm 10 \%$ o (Taylor, personal communication). However, isotope data for jarosite of supergene origin from the Pascua deposit (Deyell, 2001), located to the north of El IndioTambo, suggest that this value has been slightly lower (about $-125 \%$ o). Variations of this magnitude are expected during the 3-4 my duration of the Tambo hydrothermal system, and a range of meteoric $\delta \mathrm{D}$ values is shown on all isotope plots (Figs. 6-8) accompanying the following discussions.

Stable-isotope systematics for each paragenetic stage are presented below. For ease of data interpretation and discussion, some samples are grouped with other, related stages. In each section, $\delta^{34} \mathrm{~S}$ data are discussed first, followed by $\delta^{18} \mathrm{O}$ and $\delta \mathrm{D}$ relations. The $\delta \mathrm{D}_{\mathrm{H}_{2} \mathrm{O}}$ and $\delta^{18} \mathrm{O}_{\mathrm{H}_{2} \mathrm{O}}$ values of fluids in equilibrium with each alunite sample are calculated from the fractionation equations of Stoffregen et al. (1994) over a range of temperatures. These temperatures are estimated from textural data, $\Delta^{18} \mathrm{O}_{\mathrm{SO}_{4}-\mathrm{OH}}$ isotope fractionations, and homogenization temperatures given in Jannas et al. (1999). In general, the $\delta \mathrm{D}$ $\delta^{18} \mathrm{O}$ mineral data and calculated fluid compositions of main-stage fluids fall on trends (Figs. 6 and 7) nearly parallel to the meteoric water line. The trend is also similar to that observed for alunite in active stratovolcanoes (Zimbelman et al., this volume). These trends reflect mixing of magmatic and ${ }^{18} \mathrm{O}$ enriched meteoric water and are in contrast to the typical mixing trends between magmatic and unexchanged meteoric water commonly observed for highsulfidation ore-forming fluids (e.g., Julcani; Deen et al., 1994). To some extent, the range in $\delta \mathrm{D}$ values of alunite parental fluids may reflect the effect of significant deuterium enrichment of degassed aqueous fluid over silicate melts during Rayleigh degassing of different batches of magma throughout the period of hydrothermal alteration (Taylor, 1986, 1988, 1991). However, the data trends in Figs. 6 and 7 are not vertical, with a nearly constant $\delta^{18} \mathrm{O}$, which may indicate that some mixing of unexchanged meteoric water with the magmatic fluids occurred in the different environments. Such mixing is most obvious in the shallow and late-stage fluids (Fig. 8).

\subsection{Brecha Sylvestre, Stage 1, and Stage 2: magmatic-hydrothermal alunite}

Fig. 6 summarizes the $\delta^{34} \mathrm{~S}, \delta \mathrm{D}$, and $\delta^{18} \mathrm{O}$ values for alunite from Brecha Sylvestre, Stage 1, and Stage 2 . 
Table 5

Sample descriptions and stable isotope results for all Tambo alunite, barite, and enargite samples

\begin{tabular}{|c|c|c|c|c|c|c|c|c|c|}
\hline Sample & $\begin{array}{l}\text { Lab } \\
\text { no. }\end{array}$ & Stage & Deposit & $\begin{array}{l}\text { Elev. } \\
(\mathrm{m})\end{array}$ & Description & $\begin{array}{l}\delta \mathrm{D} \\
(\% \circ)\end{array}$ & $\begin{array}{l}\delta^{34} \mathrm{~S} \\
(\% 0)\end{array}$ & $\begin{array}{l}\delta^{18} \mathrm{O}_{\mathrm{SO}_{4}} \\
(\% o)\end{array}$ & $\begin{array}{l}\delta^{18} \mathrm{O}_{\mathrm{OH}}{ }^{\mathrm{a}} \\
(\% \circ)\end{array}$ \\
\hline \multicolumn{10}{|l|}{ Alunite } \\
\hline WND-92A, $190.0 \mathrm{~m}$ & T09a & 1 & Wendy & 4113 & Qtz-alun alteration & -98 & 6.2 & 9.4 & 3.7 \\
\hline WND-92A, $290.8 \mathrm{~m}$ & $\mathrm{~T} 10 \mathrm{a}$ & 1 & Wendy & 4135 & Qtz-alun alteration & -53 & 22.1 & 15.8 & 10.1 \\
\hline KBD- $85,16.0 \mathrm{~m}$ & T16a & 1 & Kimberly & 4113 & Qtz-alun-pyl alt & & 7.2 & & \\
\hline KBD-85, $306.8 \mathrm{~m}$ & $\mathrm{~T} 29 \mathrm{a}$ & 1 & Kimberly & 3887 & Qtz-alun alteration & -32 & 23.1 & 17.2 & 14.3 \\
\hline KBD-85, $94.1 \mathrm{~m}$ & T30a & 1 & Kimberly & 4052 & Qtz-alun alteration & -30 & 1.1 & 20.3 & 14.3 \\
\hline WND-92a, $82.7 \mathrm{~m}$ & T31a & 1 & Wendy & 4090 & Qtz-alun-dick alteration & & 12.4 & & \\
\hline RA-01 & T01a & 2 & Reina & 4010 & Vein alun with bar, walth, Au & -28 & 27.3 & 21.0 & 15.5 \\
\hline $\mathrm{RA}-4,41.6 \mathrm{~m}$ & $\mathrm{~T} 24 \mathrm{a}$ & 2 & Reina & 4025 & Coarse alun with walth & -27 & 27.4 & 20.3 & 16.3 \\
\hline CS-29 & $\mathrm{T} 26 \mathrm{a}$ & 2 & Canto Sur & 4522 & Fine-grained alun, bar with $\mathrm{Au}$ & -55 & 27.3 & 16.5 & 10.8 \\
\hline CS-01b & $\mathrm{T} 27 \mathrm{a}$ & 3 & Canto Sur & 4474 & Alun with bar in breccia matrix & -38 & 2.1 & 19.6 & 15.3 \\
\hline CS-08 & $\mathrm{T} 02 \mathrm{~b}$ & 3 & Canto Sur & 4474 & Matrix alun over bar & -78 & 1.8 & 10.1 & 3.6 \\
\hline LN-24 & T03a & 3 & Kimberly West & 4130 & Matrix alun, overgrowing T03b & -47 & 5.5 & 17.7 & 13.2 \\
\hline $\mathrm{LN}-24$ & T03b & 3 & Kimberly West & 4130 & Matrix alun, overgrowing qtz & -46 & 1.3 & 19.2 & 12.8 \\
\hline WND-86, $155.0 \mathrm{~m}$ & T04a & 3 & Wendy & 4017 & Matrix alun, with enarg and scord & -63 & 1.7 & 15.0 & 8.1 \\
\hline WND-86, 237m & T06a & 3 & Wendy & 3960 & Matrix alun hosting enarg & -85 & 1.7 & 11.9 & 5.7 \\
\hline CS-04 & $\mathrm{T} 20 \mathrm{a}$ & 3 & Canto Sur & 4475 & Matrix alun & -41 & -0.2 & & \\
\hline WND-92a, 37.5 m & $\mathrm{T} 21 \mathrm{a}$ & 3 & Wendy & 4080 & Matrix alun hosting enarg & -80 & 1.7 & 15.9 & 4.9 \\
\hline WND-92a, $231.8 \mathrm{~m}$ & $\mathrm{~T} 22 \mathrm{a}$ & 3 & Wendy & 4122 & Matrix alun & -54 & 2.8 & 19.7 & 14.7 \\
\hline KB-43 & $\mathrm{T} 23 \mathrm{a}$ & 3 & Kimberly & 4075 & Matrix alun & -79 & 0.7 & & \\
\hline LN-09 & $\mathrm{T} 25 \mathrm{a}$ & 2 & Kimberly West & 4240 & Matrix alun with bar, qtz & -42 & 25.7 & 19.6 & 16.4 \\
\hline WND-92a, $13.7 \mathrm{~m}$ & $\mathrm{~T} 28 \mathrm{a}$ & 3 & Wendy & 4075 & Fine-grained matrix alun & -98 & 2.8 & 11.1 & 3.6 \\
\hline KB-08 & T36a & 3 & Kimberly & 4050 & Matrix alun with scord & -51 & 3.5 & 18.0 & 12.0 \\
\hline KB-47 & T07a & MS & Kimberly & & Coarse banded vein with minor hem & -40 & 0.5 & 20.5 & 14.0 \\
\hline KB-33B & T08a & MS & Kimberly & 4100 & Coarse banded vein with hem & -48 & 1.1 & 16.4 & 8.8 \\
\hline WN-07 & $\mathrm{T} 32 \mathrm{a}$ & MS & Wendy & 4180 & Banded vein with hem & -69 & 1.4 & 15.9 & 9.7 \\
\hline KB-01 & T33a & MS & Kimberly & 4050 & Coarse banded vein & -60 & 0.4 & 18.8 & $15.6^{*}$ \\
\hline KB-44 & $\mathrm{T} 34 \mathrm{a}$ & MS & Kimberly & 4075 & Coarse banded vein with hem & -74 & 0.3 & 11.3 & \\
\hline KB-09 & $\mathrm{T} 14 \mathrm{a}$ & $\mathrm{Ca}$ & Kimberly & 4060 & Thin veinlet cross-cutting altered tuff & -118 & 1.8 & 11.7 & 3.2 \\
\hline LN-02 & $\mathrm{T} 35 \mathrm{a}$ & $\mathrm{Ca}$ & Kimberly West & 4260 & Thin veinlet cross-cutting altered tuff & -56 & 9.2 & 20.6 & 14.2 \\
\hline KB-37B & $\mathrm{T} 13 \mathrm{a}$ & $\mathrm{SH}$ & Kimberly & 4480 & Near-surface qtz-kao-alun-S alteration & -53 & 5.9 & 18.8 & 12.3 \\
\hline KB-40 & $\mathrm{T} 17 \mathrm{a}$ & $\mathrm{SH}$ & Kimberly & 4460 & Near-surface qtz-kao-alun-S alteration & -13 & 4.9 & 23.2 & 18.8 \\
\hline $\mathrm{WN}-14$ & $\mathrm{~T} 18 \mathrm{a}$ & $\mathrm{SH}$ & Cerro Elephante & 4450 & Powdery qtz-alun veinlets & -62 & 16.6 & 15.4 & $11.9 *$ \\
\hline CS-08 & T02a & LV & Canto Sur & 4474 & Fine-grained alun-jar over Stage 3 alun & -111 & -0.2 & 10.0 & 2.5 \\
\hline KBD-85, $306.8 \mathrm{mV}$ & T11a & LV & Kimberly & 3887 & Alun-jar veinlet in Stage 1 alteration & -110 & 5.4 & 7.0 & 1.3 \\
\hline KBD-85, $125.7 \mathrm{~m}$ & $\mathrm{~T} 12 \mathrm{a}$ & LV & Kimberly & 4027 & Alun-qtz (jar) veinlet & -57 & 2.0 & 15.7 & 9.8 \\
\hline WND-86, $226.5 \mathrm{~m}$ & $\mathrm{~T} 15 \mathrm{a}$ & LV & Wendy & 3969 & Brown jar-alun vein & -68 & 4.3 & 16.1 & 9.3 \\
\hline \multicolumn{10}{|l|}{ Barite } \\
\hline RA-01 & $\mathrm{Tb} 01$ & 2 & Reina & 4050 & Coarse vein fill, associated with T01a & & 26.8 & 13.8 & \\
\hline CS-08 & $\mathrm{Tb} 02$ & 2 & Canto Sur & 4474 & Coarse matrix crystals, with alun & & 24.5 & 17.3 & \\
\hline $\mathrm{CS}-30$ & $\mathrm{~Tb} 03$ & 2 & Canto Sur & 4396 & Coarse matrix crystals, mineralized & & 23.8 & 17.1 & \\
\hline \multicolumn{10}{|l|}{ Enargite } \\
\hline WND-86, $155.0 \mathrm{~m}$ & T04e & 3 & Wendy & 4017 & Enarg intergrown with alun & & -2.4 & & \\
\hline WND-86, 237 m & T06e & 3 & Wendy & 3960 & Enarg intergrown with alun & & -3.7 & & \\
\hline
\end{tabular}

Elevation given in meters above sea level. Abbreviated mineral names: alunite (alun), barite (bar), dickite (dick), enargite (enarg), gold (Au), hematite (hem), jarosite (jar), kaolinite (kao), pyrophyllite (pyl), quartz (qtz), scorodite (scord), native sulfur (S), walthierite (wal).

${ }^{a}$ Calculated using $\mathrm{BrF}_{5}$ total oxygen data, except samples marked by *. 


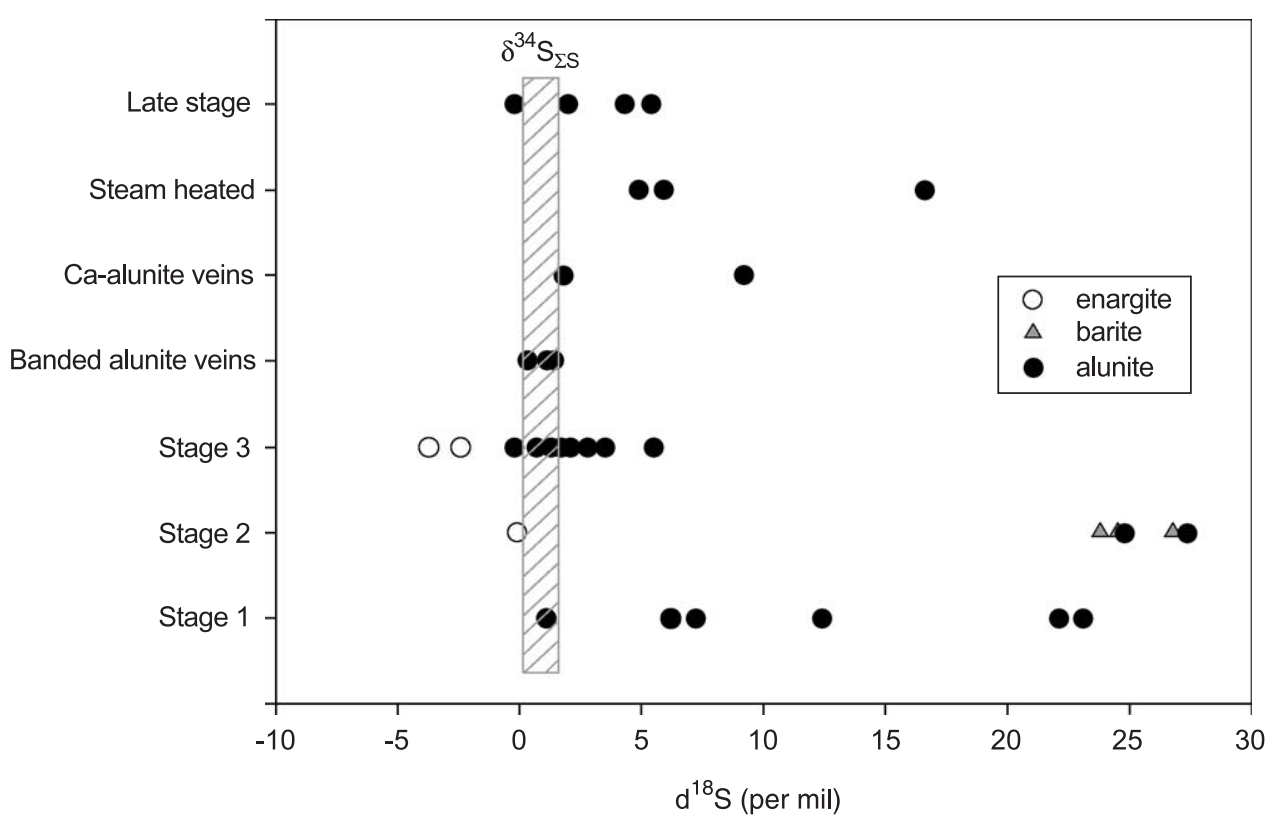

Fig. 5. Range in $\delta^{34} \mathrm{~S}$ data (in \%o) for all stages of Tambo alunite. Also shown are data for associated enargite (this study; Jannas et al., 1999) and barite from Stage 2 and Stage 3. Estimated $\delta^{34} \mathrm{~S}_{\sum \mathrm{S}}=\sim 1 \%$ o to 3\%o. See text for discussion.

Stage $1 \delta^{34} \mathrm{~S}$ values range from $1 \%$ o to $23 \%$ (Fig. 6A). Stage 2 alunite is heavier, with $\delta^{34} \mathrm{~S}$ values of $26 \%$ o to $27 \%$. Sulfur-isotope values for the two Brecha Sylvestre samples (14\%o and 15\%o) are lower than those for Stage 2 alunite, but are intermediate to those for Stage 1.

Values of $\delta \mathrm{D}$ and $\delta^{18} \mathrm{O}$ for alunite are shown in Fig. 6B, along with the range of calculated fluid compositions in equilibrium with samples from each alteration event. The composition of both the Stage 2 and Brecha Sylvestre alunite parental fluids overlap those typical of fluids in felsic magmas (Taylor, 1988). Most Stage 1 fluids also plot within this range, indicating a dominant magmatic component. In both Stages 1 and 2, there is a linear trend to lower isotopic values as discussed above.

Discussion: High $\delta^{34} \mathrm{~S}$ values for Stage 2 alunite (and barite) and fluid compositions in the magmatic range are consistent with a magmatic-hydrothermal origin for this stage of alteration. In contrast, the large range in Stage $1 \delta^{34} \mathrm{~S}$ values is unusual. The largest $\delta^{34} \mathrm{~S}$ values $(22 \%$ o to $23 \%$ ) are consistent with derivation from sulfate that equilibrated with $\mathrm{H}_{2} \mathrm{~S}$ during disproportionation of $\mathrm{SO}_{2}$ (Rye et al., 1992;
Rye, 1993), but other values are not. We propose two alternative explanations for this variability. The values may represent magmatic-hydrothermal alunite formed from aqueous sulfate-sulfur species that did not always reach isotopic equilibrium with $\mathrm{H}_{2} \mathrm{~S}$ during disproportionation of $\mathrm{SO}_{2}$. This could result from shorter residence times for aqueous sulfate during early vapor-plume development, condensation, and alunite precipitation in Stage 1. Alternatively, the values can be interpreted to indicate magmatic-hydrothermal alunite that is partly to completely replaced by either magmatic-steam or steam-heated alunite. On the basis of the textural and petrographic observations for Stage 1 alunite, the second model is preferred. Alunite with the lowest $\delta^{34} \mathrm{~S}$ values has macroscopic characteristics of Stage 1 alteration, but these grains appear to have precipitated in vugs created by the leaching of feldspar phenocrysts. Partial replacement of APS-bearing alunite by a more homogeneous, K-rich variety is also observed in one sample. Similar processes are inferred at El Salvador (Watanabe and Hedenquist, 2001), where partial replacement of hypogene by supergene alunite resulted in intermediate $\delta^{34} \mathrm{~S}$ values. One 

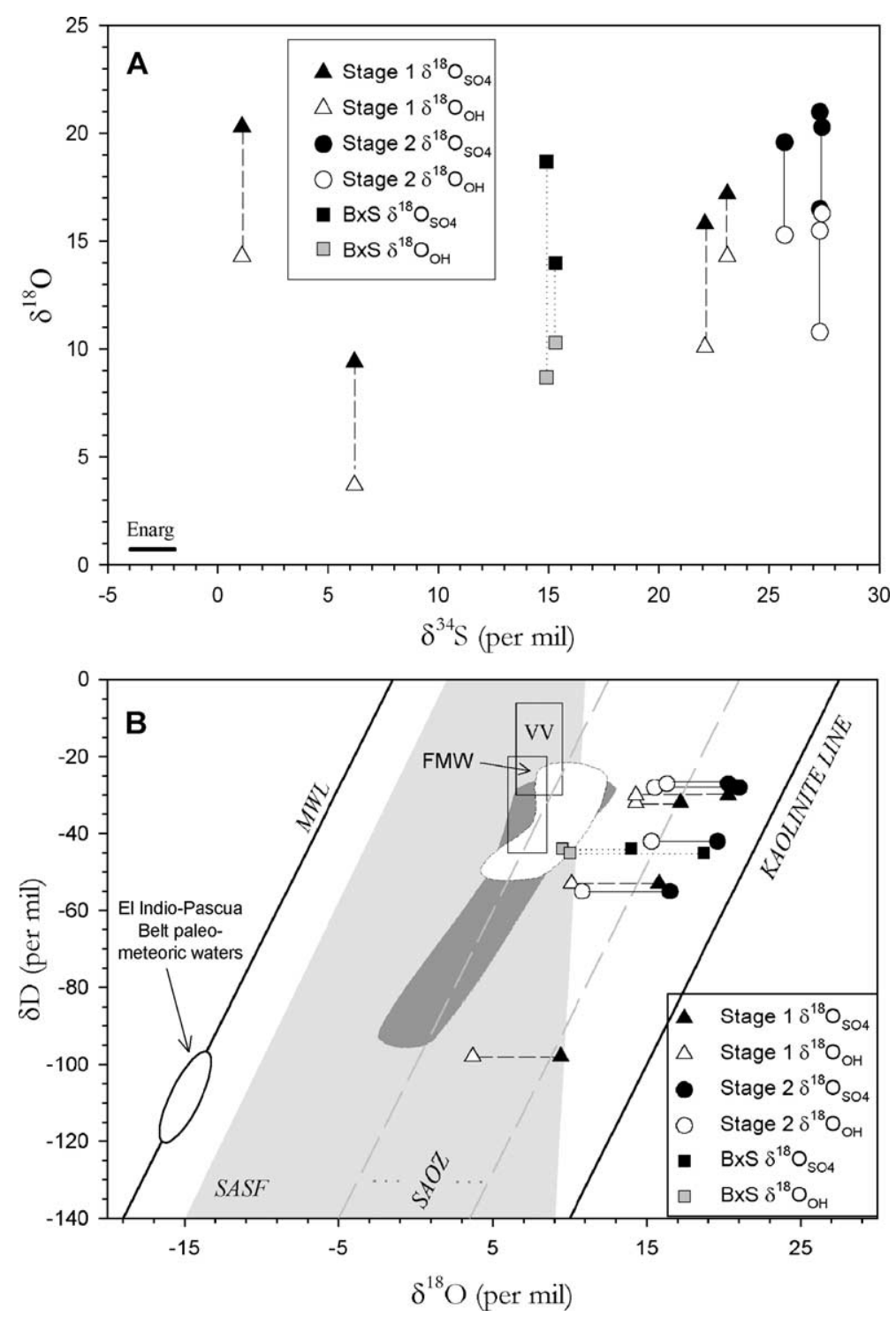

Fig. 6. (A) Data for $\delta^{34} \mathrm{~S}$ and $\delta^{18} \mathrm{O}$ (in \%o) for alunite from Stage 1, Stage 2, and Brecha Sylvestre (BxS). The $\delta^{18} \mathrm{O}_{\mathrm{SO}_{4}}$ and $\delta^{18} \mathrm{O}_{\mathrm{OH}}$ values for each sample are joined by lines. Range of $\delta^{34} \mathrm{~S}$ data for associated sulfides is also given. (B) Values of $\delta \mathrm{D}, \delta^{18} \mathrm{O}_{\mathrm{SO}_{4}}$, and $\delta^{18} \mathrm{O}_{\mathrm{OH}}$ for alunite from Stage 1, Stage 2, and Brecha Sylvestre (BxS). Ranges of calculated $\delta \mathrm{D}_{\mathrm{H}_{2} \mathrm{O}}$ and $\delta^{18} \mathrm{O}_{\mathrm{H}_{2} \mathrm{O}}$ for fluids in equilibrium with each stage are shown as shaded fields (gray=Stage $1,200-280{ }^{\circ} \mathrm{C}$; white=Stage 2, 180-250 ${ }^{\circ} \mathrm{C}$ ). Lines and fields are: $\mathrm{MWL}=$ meteoric water line of Craig $(1961)$; kaolinite line of Savin and Epstein (1970); V.V. (volcanic vapor)=range of water compositions discharged from high-temperature fumaroles (Giggenbach, 1992); SASF (light gray)=supergene alunite $\mathrm{SO}_{4}$ field; and $\mathrm{SAOZ}=$ supergene alunite $\mathrm{OH}$ zone as described by Rye et al. (1992). The white circle is the estimated composition of paleo-meteoric waters.

alunite sample has a significantly lower $\delta \mathrm{D}_{\mathrm{H}_{2} \mathrm{O}}$ $(-94 \%)$ and larger $\delta^{18} \mathrm{O}_{\mathrm{SO}_{4}}$ values $(7.0 \%)$, which suggests mixing of isotopically heavy magmatic fluids with ${ }^{18} \mathrm{O}$-enriched meteoric fluids (due to exchange, boiling, or evaporation).

\subsection{Stage 3 and banded alunite veins; transitional and magmatic-steam alunite}

Fig. 7 summarizes the $\delta^{34} \mathrm{~S}, \delta \mathrm{D}$, and $\delta^{18} \mathrm{O}$ values for Stage 3 and banded-vein alunite. The $\delta^{34} \mathrm{~S}$ values 

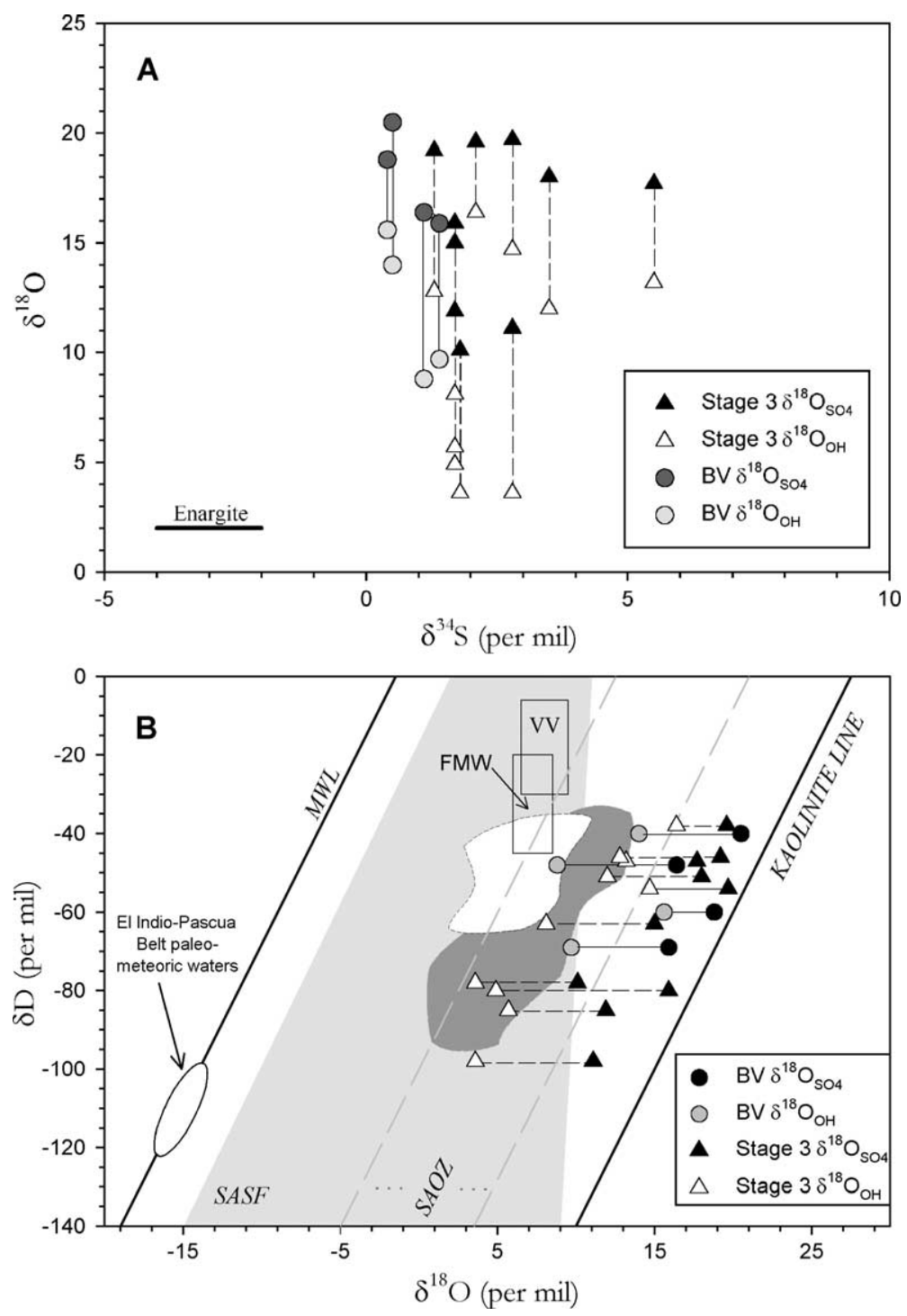

Fig. 7. (A) Data for $\delta^{34} \mathrm{~S}$ and $\delta^{18} \mathrm{O}$ (in \%o) for Stage 3 and banded vein (BV) alunite. The $\delta^{18} \mathrm{O}_{\mathrm{SO}_{4}}$ and $\delta^{18} \mathrm{O}_{\mathrm{OH}}$ values for each sample are joined by lines. Range of $\delta^{34} \mathrm{~S}$ data for Tambo sulfides is also given. (B) Values of $\delta \mathrm{D}, \delta^{18} \mathrm{O}_{\mathrm{SO}_{4}}$, and $\delta^{18} \mathrm{O}_{\mathrm{OH}}$ for Stage 3 and banded vein (BV) alunite. Range of calculated $\delta \mathrm{D}_{\mathrm{H}_{2} \mathrm{O}}$ and $\delta{ }^{18} \mathrm{O}_{\mathrm{H}_{2} \mathrm{O}}$ for fluids in equilibrium with each stage is shown as shaded fields (gray=Stage 3, 200-300 ${ }^{\circ} \mathrm{C}$; white $=$ BV, $200-300{ }^{\circ} \mathrm{C}$ ). Fluid compositions calculated from equations of Stoffregen et al. (1994). Lines and fields are as given in Fig. 6.

for both events are slightly greater than the values of Stage 3 enargite (about $-2 \%$ o to $-4 \%$ ). Banded-vein alunite has consistently lower $\delta^{34} \mathrm{~S}$ values (about $0 \%$ o to $1.5 \%$ ) than Stage 3 samples. Only minor variation in $\delta^{34} \mathrm{~S}$ is reported for different banded-vein samples or for growth bands in a single vein (Deyell, 2001). The narrow range of values for both banded-vein and Stage 3 alunite indicates that sulfur-isotope equili- brium was not attained between aqueous sulfate and $\mathrm{H}_{2} \mathrm{~S}$.

Calculated fluid compositions for alunite are shown in Fig. 7B. Stage 3 fluids have $\delta \mathrm{D}_{\mathrm{H}_{2} \mathrm{O}}$ values between about $-30 \%$ and $-95 \%$, and $\delta^{18} \mathrm{O}_{\mathrm{H}_{2} \mathrm{O}}$ values between $-1 \%$ and $13 \%$. The values for fluids from banded-vein alunite have a more restricted range, with $\delta \mathrm{D}_{\mathrm{H}_{2} \mathrm{O}}$ between $-35 \%$ and $-65 \%$ o. Data 

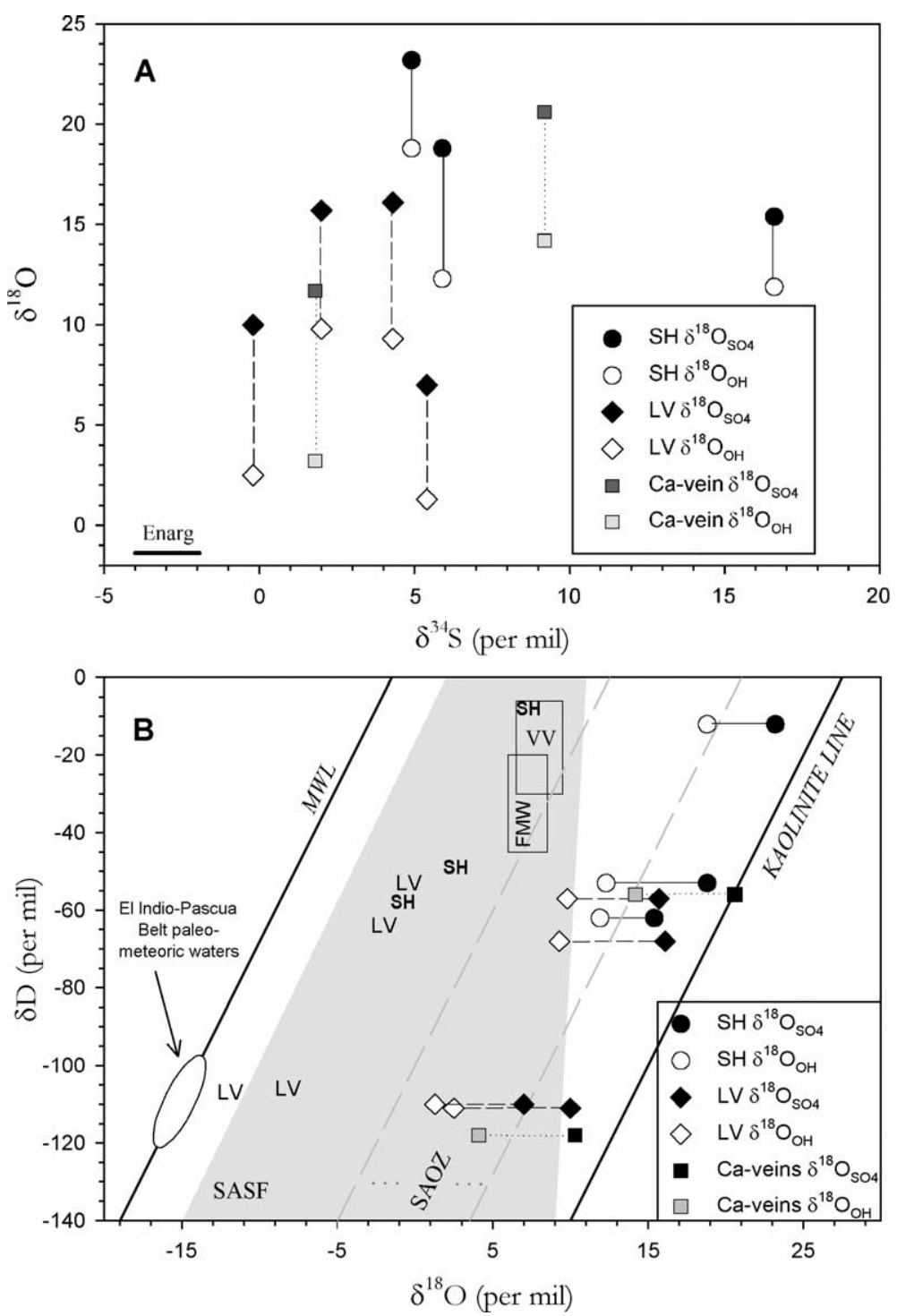

Fig. 8. (A) Data for $\delta^{34} \mathrm{~S}$ and $\delta^{18} \mathrm{O}$ (in \%o) for steam-heated (SH), late vein (LV), and huangite-bearing vein (Ca-vein) alunite. The $\delta^{18} \mathrm{O}_{\mathrm{SO}_{4}}$ and $\delta^{18} \mathrm{O}_{\mathrm{OH}}$ values for each sample are joined by lines. Range of $\delta^{34} \mathrm{~S}$ data for Tambo sulfides is given for reference. (B) Values of $\delta \mathrm{D}, \delta^{18} \mathrm{O}_{\mathrm{SO}_{4}}$, and $\delta^{18} \mathrm{O}_{\mathrm{OH}}$ for steam-heated (SH), late vein (LV) and huangite-bearing vein (Ca-vein) alunite. Ranges of calculated $\delta \mathrm{D}_{\mathrm{H}_{2} \mathrm{O}}$ and $\delta^{18} \mathrm{O}_{\mathrm{H}_{2} \mathrm{O}}$ for fluids in equilibrium with each stage are shown as symbols ( $\mathrm{SH}=$ steam-heated fluids, $130{ }^{\circ} \mathrm{C}$; $\mathrm{LV}=$ late-vein fluids, $\left.80{ }^{\circ} \mathrm{C}\right)$. Lines and fields are as given in Fig. 6.

for both events overlap those typical of magmatic waters in felsic magmas (Taylor, 1988), but the fluids for Stage 3 and the banded veins are typically depleted in deuterium and enriched in ${ }^{18} \mathrm{O}$ relative to Stage 2 magmatic-hydrothermal fluids.

Discussion: Data for banded-vein alunite indicate a major magmatic component in the source fluids. Results are consistent with a magmaticsteam origin. Stage 3 data are more variable and show greater degrees of mixing between magmatic and meteoric fluids. The larger range of $\delta^{34} \mathrm{~S}$ values for alunite of this stage suggests limited exchange between aqueous sulfur species. Deposition is thought to have occurred in an environment 
that is transitional between magmatic-hydrothermal and magmatic-steam.

Depositional temperatures calculated from $\Delta^{18} \mathrm{O}_{\mathrm{SO}_{4}-\mathrm{OH}}$ for banded-vein alunite average about $110{ }^{\circ} \mathrm{C}$, with the exception of one higher value at $320{ }^{\circ} \mathrm{C}$ (sample T33a). Independent estimates of temperature are not available for this stage of alteration, but temperatures are expected to be at least as high as those encountered in the magmatichydrothermal environment (i.e., $180-300{ }^{\circ} \mathrm{C}$ ). The effects related to retrograde isotopic exchange are not expected given the coarse grain size of the alunite; hence, the origin of the low values for $\delta^{18} \mathrm{O}_{\mathrm{OH}}$ is unclear. Similar behavior has been reported for magmatic-steam alunite at Alunite Ridge, Marysvale, UT (Rye et al., 1992).

The range in $\Delta^{18} \mathrm{O}_{\mathrm{SO}_{4}-\mathrm{OH}}$ temperatures for Stage 3 alunite is greater than for the banded-veins (10-330 ${ }^{\circ} \mathrm{C}$ ), but most values are below $200{ }^{\circ} \mathrm{C}$. Again, several temperatures are unreasonably low but others are within the expected range for shallow environments of deposition.

As discussed above, the correlation between decreasing $\delta \mathrm{D}_{\mathrm{H}_{2} \mathrm{O}}$ and $\delta^{18} \mathrm{O}_{\mathrm{H}_{2} \mathrm{O}}$ values for both alunite types does not project back to the meteoric water line. This trend can be attributed to mixing of magmatic and ${ }^{18} \mathrm{O}$-enriched (from exchange, boiling, or evaporation) meteoric water.

\subsection{Huangite-bearing vein alunite}

The $\delta^{34} \mathrm{~S}, \delta \mathrm{D}$, and $\delta^{18} \mathrm{O}$ values for two samples of huangite-bearing vein alunite are plotted in Fig. 8 . Results for the two samples are significantly different. One sample has low $\delta^{34} \mathrm{~S}(1.8 \% 0)$ and $\delta^{18} \mathrm{O}_{\mathrm{SO}_{4}}$ $\left(11.7 \%\right.$ ) values. The other sample has a $\delta^{34} \mathrm{~S}$ value of about $9 \%$, and has a $\delta^{18} \mathrm{O}$ value in the range of magmatic-hydrothermal alunite. Calculated $\delta \mathrm{D}_{\mathrm{H}_{2} \mathrm{O}}$ values in equilibrium with the two samples are $-115 \%$ and $-52 \%$, respectively. The first sample (T35) has a fluid composition which overlaps that of Tambo magmatic-hydrothermal and magmatic-steam fluids. Data for the latter (sample T14a) indicate a significant ${ }^{18} \mathrm{O}$-enriched meteoric fluid component or a highly fractionated late-stage magmatic fluid with a minor component of unexchanged meteoric water.

Discussion: Depositional temperatures for the two huangite-bearing samples, on the basis of $\Delta^{18} \mathrm{O}_{\mathrm{SO}_{4}-\mathrm{OH}}$ values, are similar and average $105{ }^{\circ} \mathrm{C}$. No independent temperature estimates are available for these veins, however, and it is unclear whether these values are reasonable. Temperatures of formation for the mineralogically similar El Indio Campana vein were estimated to be $225-275^{\circ} \mathrm{C}$ (Jannas, 1995), but lower temperature occurrences of Ca-rich alunite have been reported elsewhere (e.g., Stoffregen and Alpers, 1987; Arribas et al., 1995). The origin of these veins and their relation to other alteration or mineralizing events is uncertain.

\subsection{Near-surface alteration}

Fig. 8 summarizes the $\delta^{34} \mathrm{~S}, \delta \mathrm{D}$, and $\delta^{18} \mathrm{O}$ data for alunite sampled from the near-surface alteration blanket on Cerro Elefante. Two samples (T13, T17) have $\delta^{34} \mathrm{~S}$ values slightly enriched relative to those of the bulk sulfur in the deposit, and have high $\delta^{18} \mathrm{O}_{\mathrm{SO}_{4}}$ values. The third sample (T18), selected from white, powdery veins that crosscut Stage 1 alteration just below the blanket zone, has a much larger $\delta^{34} \mathrm{~S}$ value (16.6\%o) and lower $\delta^{18} \mathrm{O}_{\mathrm{SO}_{4}}$ value (15.4\%o) than those of the first two samples.

Calculated fluid compositions in equilibrium with alunite are plotted in Fig. $8 \mathrm{~B}$. Values of $\delta \mathrm{D}_{\mathrm{H}_{2} \mathrm{O}}$ for the first two samples vary between about $-10 \%$ and $-55 \%$ o, with $\delta^{18} \mathrm{O}_{\mathrm{H}_{2} \mathrm{O}}$ between $2 \%$ o and $7 \%$ o. These values are significantly enriched relative to those for meteoric water, and indicate a dominant magmatic fluid component. Deuterium enrichment by evaporation (Henley and Stewart, 1983) is inferred for the highest $\delta \mathrm{D}$ value.

Discussion: Sulfur and oxygen isotopic data for this stage of alteration are consistent with a steam-heated origin. Limited sulfur-isotope exchange between aqueous $\mathrm{SO}_{4}$ and $\mathrm{H}_{2} \mathrm{~S}$ is inferred for the first two samples. Calculated $\Delta{ }^{18} \mathrm{O}_{\mathrm{SO}_{4}-\mathrm{OH}}$ temperatures of deposition are 110 and $210{ }^{\circ} \mathrm{C}$. Results are reasonable, although perhaps slightly high in the latter, for environments in which aqueous sulfate forms at shallow levels from the oxidation of $\mathrm{H}_{2} \mathrm{~S}$ by atmospheric oxygen (Rye et al., 1992; Ebert and Rye, 1997). Oxygen isotopic temperatures also suggest that oxygen-isotope equilibrium was obtained between the aqueous sulfate and water in the fluid. The third sample, given its shallow depth, has an unreasonably high $\Delta^{18} \mathrm{O}_{\mathrm{SO}_{4}-\mathrm{OH}}$ temperature of 290 ${ }^{\circ} \mathrm{C}$, although $\delta^{18} \mathrm{O}_{\mathrm{OH}}$ values are in the range of those for 
the previous two samples. Significant isotopic exchange of $\mathrm{S}$ occurred between aqueous $\mathrm{SO}_{4}$ and $\mathrm{H}_{2} \mathrm{~S}$, but $\Delta{ }^{18} \mathrm{O}_{\mathrm{SO}_{4}-\mathrm{OH}}$ may have also been affected by post-depositional exchange.

\subsection{Alunite in late veins}

Sulfur data for late-vein alunite are slightly greater than values for sulfides in the deposit (Fig. 8A). All $\delta^{18} \mathrm{O}_{\mathrm{OH}}$ values plot within the Supergene Alunite $\mathrm{OH}$ Zone (SAOZ) defined by Rye et al. (1992); however, all but one of the $\delta^{18} \mathrm{O}_{\mathrm{SO}_{4}}$ values plot outside of the Supergene Alunite Sulfate Field (SASF; Rye et al., 1992). These results, combined with large positive $\Delta^{18} \mathrm{O}_{\mathrm{SO}_{4}-\mathrm{OH}}$ values, are not consistent with a supergene origin. Similarly, calculated $\Delta^{18} \mathrm{O}_{\mathrm{SO}_{4}-\mathrm{OH}}$ temperatures average about $100{ }^{\circ} \mathrm{C}$ and are higher than expected for deposition in the supergene environment.

Calculated fluid compositions in equilibrium with alunite samples are shown in Fig. 8B. The data fall on a trend that projects, at low $\delta \mathrm{D}$ values, close to the meteoric water line. Two samples with the lowest $\delta \mathrm{D}_{\mathrm{H}_{2} \mathrm{O}}$ and $\delta^{18} \mathrm{O}_{\mathrm{H}_{2} \mathrm{O}}$ values have fluids close to the predicted composition of meteoric waters. The other two samples have much larger $\delta \mathrm{D}_{\mathrm{H}_{2} \mathrm{O}}$ and $\delta^{18} \mathrm{O}_{\mathrm{H}_{2} \mathrm{O}}$ values, indicating a substantial magmatic contribution. These fluid compositions overlap those for magmatic-hydrothermal and magmatic-steam occurrences.

Discussion: Results indicate that the late alunite veins were not generated under typical supergene conditions even though they have a field appearance suggestive of a supergene origin. This type of alunite formed from mixed magmatic-meteoric fluids at moderate temperatures, $\sim 100{ }^{\circ} \mathrm{C}$. The meteoric water component was only moderately enriched in ${ }^{18} \mathrm{O}$. The small amount of sulfides in the orebody and surrounding host rock may indicate that some of the aqueous sulfate for the late alunite was derived from oxidation of $\mathrm{H}_{2} \mathrm{~S}$.

\section{Geochemistry of alunite}

Major- and trace-element analyses were determined to evaluate the compositional variability of alunite and alunite-group minerals in each alteration stage. End- member alunite is $\mathrm{KAl}_{3}\left(\mathrm{SO}_{4}\right)_{2}(\mathrm{OH})_{6}$, but naturally occurring minerals of the alunite supergroup can have a wide range of chemical substitutions (Jambor, 1999). The most common substitution of $\mathrm{Na}$ for $\mathrm{K}$ defines the alunite-natroalunite solid solution. Other substitutions for $\mathrm{K}^{+}$may include $\mathrm{Ca}, \mathrm{Ba}, \mathrm{Sr}$, REE, $\mathrm{Pb}, \mathrm{Ag}, \mathrm{H}_{3} \mathrm{O}$, and $\mathrm{NH}_{4}$. Substitution of $\mathrm{Fe}^{3+}$ for $\mathrm{Al}^{3+}$ defines the alunitejarosite solid solution, and substitution of $\left(\mathrm{PO}_{4}\right)^{3-}$ for $\left(\mathrm{SO}_{4}\right)^{2-}$ forms APS minerals of the crandallite and beudantite groups (Table 3: as summarized in Jambor, 1999). Several experimental (Hemley et al., 1969; Stoffregen and Cygan, 1990) and empirical studies (e.g., Aoki, 1991; Aoki et al., 1993; Thompson, 1992; Hedenquist et al., 1994; Arribas et al., 1995) have correlated variations in alunite-group chemistry to specific environments or temperatures of deposition. Similarly, published data on REE contents of acidsulfate-altered rocks suggest that REE contents may be influenced by a number of factors, including (a) crystallographic controls (Schwab et al., 1990); (b) the availability and type of complexing agents (Wood, 1990a,b; Lottermoser, 1992); and (c) environmental controls such as $\mathrm{pH}$, Eh, and temperature (e.g., Michard, 1989). REE partitioning between magmatic vapors and melts (Flynn and Burnham, 1978; Candela and Piccoli, 1995; Reed, 1995) may also affect the REE content of any alteration or ore minerals that form from the condensation of magmatic fluids in the epithermal environment.

\subsection{Summary of results}

Chemical data for each stage of Tambo alunite are given in Tables $6 \mathrm{a}$ and $6 \mathrm{~b}$, which includes a summary of EPMA data for all analyses of alunite, and ICP-MS trace-metal concentrations for selected samples. REE results in this study (Fig. 9) are normalized to the average REE contents of unaltered host rock (Tilito Formation: Table 2). Our interpretation of EPMA results is limited by the large beam size required for analysis (see Section 3). Most fine-grained alunite samples, particularly supergene and steam-heated samples, were too small to be analyzed by this method and relatively few good analyses were obtained. Similarly, thin oscillatory zones and growth bands (locally $<10 \mu \mathrm{m}$ ) could not be analyzed. In such cases, results represent an average over multiple compositional bands. 
Table 6a

Summary of EPMA data for all Tambo alunite-group samples

\begin{tabular}{|c|c|c|c|c|c|c|c|c|c|c|c|c|}
\hline & \multicolumn{4}{|c|}{ Stage 1} & \multicolumn{4}{|c|}{ Stage 2} & \multicolumn{4}{|c|}{ Stage 3} \\
\hline & \multicolumn{4}{|c|}{$n=85$ (5 samples) } & \multicolumn{4}{|c|}{$n=59$ (4 samples) } & \multicolumn{4}{|c|}{$n=76$ (3 samples) } \\
\hline & Mean & $2 \sigma$ & Max & Min & Mean & $2 \sigma$ & Max & Min & Mean & $2 \sigma$ & Max & Min \\
\hline K & 0.81 & 0.46 & 1.03 & - & 0.58 & 0.80 & 1.04 & 0.02 & 0.89 & 0.31 & 1.05 & 0.26 \\
\hline $\mathrm{Na}$ & 0.19 & 0.34 & 0.81 & - & 0.09 & 0.27 & 0.90 & - & 0.11 & 0.26 & 0.62 & - \\
\hline $\mathrm{Ca}$ & 0.03 & 0.27 & 0.83 & - & - & - & 0.02 & - & - & - & 0.02 & - \\
\hline $\mathrm{Ba}$ & - & - & 0.03 & - & 0.18 & 0.40 & 0.51 & - & - & - & 0.06 & - \\
\hline $\mathrm{Sr}$ & - & - & 0.09 & - & - & - & - & - & - & - & - & - \\
\hline $\mathrm{Fe}$ & - & - & 0.06 & - & 0.04 & 0.55 & 2.13 & - & - & - & 0.17 & - \\
\hline $\mathrm{Al}$ & 3.08 & 0.12 & 3.25 & 2.95 & 3.11 & 0.55 & 3.26 & 1.14 & 3.16 & 0.13 & 3.29 & 3.01 \\
\hline $\mathrm{P}$ & 0.05 & 0.43 & 1.35 & - & - & - & 0.05 & - & - & - & 0.06 & - \\
\hline S & 1.95 & - & 2.00 & 0.65 & 1.99 & 0.02 & 2.00 & 1.95 & 1.99 & 0.03 & 2.00 & 1.94 \\
\hline
\end{tabular}

\begin{tabular}{|c|c|c|c|c|c|c|c|c|c|c|c|c|}
\hline & Bandec & & & & Steam- & & & & Late-st & & & \\
\hline & $n=33$ & mples) & & & $n=31$ & mples) & & & $n=11$ & nples) & & \\
\hline & Mean & $2 \sigma$ & Max & Min & Mean & $2 \sigma$ & Max & Min & Mean & $2 \sigma$ & Max & Min \\
\hline K & 0.87 & 0.20 & 1.02 & 0.61 & 0.98 & 0.10 & 1.04 & 0.84 & 0.92 & 0.10 & 1.02 & 0.85 \\
\hline $\mathrm{Na}$ & 0.10 & 0.15 & 0.33 & - & 0.04 & 0.08 & 0.16 & - & 0.12 & 0.10 & 0.21 & 0.02 \\
\hline $\mathrm{Ca}$ & - & - & - & - & - & - & 0.03 & - & - & - & 0.02 & - \\
\hline $\mathrm{Ba}$ & - & - & 0.04 & - & - & - & - & - & - & - & - & - \\
\hline $\mathrm{Sr}$ & - & - & 0.02 & - & - & - & - & - & - & - & - & - \\
\hline $\mathrm{Fe}$ & - & - & - & - & - & - & 0.02 & - & 0.04 & 0.11 & 0.21 & - \\
\hline $\mathrm{Al}$ & 3.14 & 0.11 & 3.24 & 3.04 & 3.13 & 0.09 & 3.23 & 3.05 & 3.13 & 0.18 & 3.25 & 2.94 \\
\hline $\mathrm{P}$ & 0.02 & 0.04 & 0.08 & - & - & - & 0.03 & - & - & - & 0.04 & - \\
\hline $\mathrm{S}$ & 1.98 & 0.04 & 2.00 & 1.92 & 1.99 & 0.02 & 2.00 & 1.97 & 1.99 & 0.02 & 2.00 & 1.96 \\
\hline
\end{tabular}

Results are in atoms per formula unit (a.p.f.u.) calculated for $(\mathrm{P}, \mathrm{S}) \mathrm{O}_{4}=2$ (Jambor, 1999). Data below detection limits (0.02 a.p.f.u. for Na and 0.01 for all other elements) are not shown. $n=$ total number of analyses.

Magmatic-hydrothermal alunite, which includes Brecha Sylvestre, Stage 1, and Stage 2 samples, exhibits a wide range of compositions. Samples of Brecha Sylvestre alunite are compositionally simple, with local enrichment in $\mathrm{Pb}$ and $\mathrm{Sb}$, minor $\mathrm{Na}$, and trace $\mathrm{P}, \mathrm{Sr}$, and $\mathrm{Ba}$. Alunite is depleted in REE relative to host-rock values, and moderate fractionation in heavy-REE (HREE) is apparent. In contrast, Stage 1 alunite is chemically heterogeneous, with irregular trace-element $(\mathrm{Na}, \mathrm{Ca}, \mathrm{Ba}, \mathrm{P}, \mathrm{Sr})$ substitution. Average $\mathrm{Na}$ contents are the highest among the analyzed alunite types (statistically significant at $95 \%$ confidence limit, based on $t$-test results). Substitutions by $\mathrm{Ca}$ and $\mathrm{Ba}$ locally approach huangite and walthierite end-member compositions. REE results show Stage 1 alunite samples are depleted in mid-REE (MREE) relative to the host Tilito Formation, and exhibit minor light-REE (LREE) fractionation.
Stage 2 alunite has a unique geochemical signature characterized by high $\mathrm{Ba}$ and the presence of walthierite. Compositions intermediate between walthierite and alunite are common, and a nearly complete range of solid-solution compositions was measured (Fig. 10). Stage 2 alunite in the Kimberly and Canto Sur deposits is commonly oscillatory zoned (Fig. 4c), typically with a core of Na-bearing alunite overgrown by walthierite and rimmed by nearly stoichiometric alunite. Walthierite has not been identified in the Wendy breccia, and Stage 2 alunite in this area occurs as coarse bladed crystals that are zoned in $\mathrm{Ca}, \mathrm{Na}, \mathrm{P}$, and minor $\mathrm{Ba}$. Stage 2 alunite is typically Na-poor $(<0.2$ atoms per formula unit-a.p.f.u.), although the mineral locally approaches natroalunite end-member compositions. Barium, $\mathrm{Pb}, \mathrm{Sb}$, and $\mathrm{Ag}$ contents on average are the highest in Stage 2 compared to the contents in other alunite types. Stage 2 alunite 
Table 6b

ICP-MS trace-element and REE concentrations (ppm) for bulk $(\sim 1 \mathrm{~g})$ alunite samples

\begin{tabular}{|c|c|c|c|c|c|c|c|c|}
\hline \multirow[t]{2}{*}{ Sample } & \multicolumn{2}{|c|}{ Stage $1^{\mathrm{a}}$} & \multirow{2}{*}{$\frac{\text { Stage } 2}{\text { T01 }}$} & \multicolumn{5}{|l|}{ Stage 3} \\
\hline & T09 & $\mathrm{T} 10$ & & $\mathrm{~T} 27$ & T03b & T04 & $\mathrm{T} 22$ & $\mathrm{~T} 28$ \\
\hline $\mathrm{P}$ & 970 & 380 & 1570 & 120 & 1180 & 1210 & 1700 & 1270 \\
\hline $\mathrm{Sr}$ & 668 & 208 & 511 & 461 & 411 & 696 & 728 & 1580 \\
\hline $\mathrm{Ba}$ & 340 & 630 & 4080 & 3850 & 3600 & 600 & 280 & 1470 \\
\hline $\mathrm{Pb}$ & 116 & 856 & 1515 & 1745 & 251 & 608 & 428 & 338 \\
\hline $\mathrm{Sb}$ & - & 11 & 317 & 10 & 10 & 29.5 & 31 & 15 \\
\hline $\mathrm{Ag}$ & 2.7 & 0.9 & 79.4 & 4.0 & 5.8 & 21.4 & 0.2 & 3.0 \\
\hline $\mathrm{Cu}$ & 1218 & 10 & 32 & 20 & 17 & 53 & 18 & 69 \\
\hline $\mathrm{Bi}$ & 22 & 1.5 & 6.5 & 0.8 & 13.4 & 102.0 & 2.3 & 32.0 \\
\hline $\mathrm{Zn}$ & 4 & 2 & - & 2 & 6 & 48 & - & 46 \\
\hline $\mathrm{La}$ & 45.3 & 25.5 & 10.5 & 13.3 & & 66.5 & 90.3 & \\
\hline $\mathrm{Ce}$ & 86.5 & 45 & 9.5 & 9.2 & & 79.5 & 81.3 & \\
\hline $\operatorname{Pr}$ & 9.2 & 4.3 & 0.6 & 0.5 & & 4.1 & 5.1 & \\
\hline $\mathrm{Nd}$ & 24.8 & 11.5 & 1.5 & 0.8 & & 6 & 6.8 & \\
\hline $\mathrm{Sm}$ & 3.3 & 1.6 & 0.2 & - & & 0.2 & 0.1 & \\
\hline $\mathrm{Eu}$ & 0.3 & 0.3 & 0.2 & 0.2 & & 0.2 & 0.1 & \\
\hline Gd & 1.8 & 1.3 & 0.1 & - & & 0.3 & 0.1 & \\
\hline $\mathrm{Tb}$ & 0.2 & 0.3 & - & - & & - & - & \\
\hline Dy & 1 & 1.1 & - & - & & 0.2 & - & \\
\hline Ho & 0.2 & 0.3 & - & - & & - & - & \\
\hline $\mathrm{Er}$ & 1 & 1.1 & - & - & & - & - & \\
\hline $\mathrm{Tm}$ & 0.1 & 0.3 & - & - & & - & - & \\
\hline $\mathrm{Yb}$ & 1.4 & 1.6 & - & - & & - & - & \\
\hline $\mathrm{Lu}$ & 0.2 & 0.3 & - & - & & - & - & \\
\hline
\end{tabular}

\begin{tabular}{|c|c|c|c|c|c|c|c|}
\hline \multirow[t]{2}{*}{ Sample } & \multirow{2}{*}{$\frac{\text { Bx Sylvestre }}{\mathrm{B} 03}$} & \multicolumn{2}{|c|}{ Banded vein } & \multirow{2}{*}{$\frac{\mathrm{Ca}-\mathrm{V}}{\mathrm{T} 14}$} & \multirow{2}{*}{$\frac{\mathrm{SH}}{\mathrm{T} 17}$} & \multicolumn{2}{|c|}{ Late-stage } \\
\hline & & $\mathrm{T} 33$ & $\mathrm{~T} 32$ & & & $\mathrm{~T} 11$ & $\mathrm{~T} 02 \mathrm{~A}$ \\
\hline $\mathrm{P}$ & 680 & 2300 & 1410 & 630 & 940 & 1490 & 1580 \\
\hline $\mathrm{Sr}$ & 511 & 1535 & 582 & 246 & 353 & 2760 & 677 \\
\hline $\mathrm{Ba}$ & 650 & 1120 & 450 & 830 & 1030 & 2140 & 2430 \\
\hline $\mathrm{Pb}$ & 1700 & 580 & 628 & 59 & 916 & 486 & 2240 \\
\hline $\mathrm{Sb}$ & 78.5 & 28.5 & 22 & 0.5 & 10 & 14.5 & 14.3 \\
\hline $\mathrm{Ag}$ & 0.8 & - & 0.6 & - & 1.4 & 3.0 & 7.9 \\
\hline $\mathrm{Cu}$ & 25 & 18 & 19 & 18 & 44 & 44 & 1 \\
\hline $\mathrm{Bi}$ & 29.2 & 0.3 & 46.2 & 0.6 & 1.0 & 32.3 & 6.0 \\
\hline $\mathrm{Zn}$ & 2 & - & 2 & 8 & 18 & 70 & - \\
\hline $\mathrm{La}$ & 33 & 156 & 81.5 & 48 & 47.5 & 29 & 77 \\
\hline $\mathrm{Ce}$ & 3 & 198 & 116.5 & 109.5 & 85 & 50 & 47 \\
\hline $\operatorname{Pr}$ & 8 & 13.4 & 7.9 & 15.5 & 8.7 & 5.9 & 2.1 \\
\hline $\mathrm{Nd}$ & 0.6 & 24 & 13 & 65.5 & 27.5 & 22 & 3 \\
\hline $\mathrm{Sm}$ & 0.1 & 1.1 & 0.6 & 16.8 & 3.7 & 5 & 0.2 \\
\hline $\mathrm{Eu}$ & 0.5 & 0.3 & 0.1 & 2.5 & 0.5 & 0.9 & 0.4 \\
\hline Gd & - & 1 & 0.5 & 9.3 & 2.3 & 3.2 & 0.1 \\
\hline $\mathrm{Tb}$ & 0.1 & 0.1 & - & 0.6 & 0.2 & 0.4 & - \\
\hline Dy & - & 0.3 & 0.1 & 0.7 & 0.7 & 1.1 & - \\
\hline Ho & 0.1 & - & - & - & 0.1 & 0.1 & - \\
\hline $\mathrm{Er}$ & - & 0.1 & - & - & 0.5 & 0.3 & - \\
\hline $\mathrm{Tm}$ & 0.1 & - & - & - & - & - & - \\
\hline $\mathrm{Yb}$ & - & 0.1 & - & 0.1 & 0.8 & 0.3 & 0.1 \\
\hline $\mathrm{Lu}$ & & - & - & - & 0.1 & - & - \\
\hline
\end{tabular}

${ }^{a}$ Trace contaminants may be present. Detection limits (ppm) are: $\mathrm{P}(10), \mathrm{Sr}(0.2), \mathrm{Ba}(0.5), \mathrm{Pb}(2), \mathrm{Sb}(2), \mathrm{Ag}(0.05), \mathrm{Cu}(0.02), \mathrm{Bi}(0.01)$, $\mathrm{Zn}$ (2), REE (0.1). Data below detection not shown. Precision estimates, based on duplicate analyses, are better than stated value at $95 \%$ confidence limit, 90th percentile: La, Ce, $\operatorname{Pr}(5 \%)$, all other REE (10\%), P, Sr, Sb, Ni (10\%), Ba (15\%), Ag, Cu (22\%), Zn (55\%). 

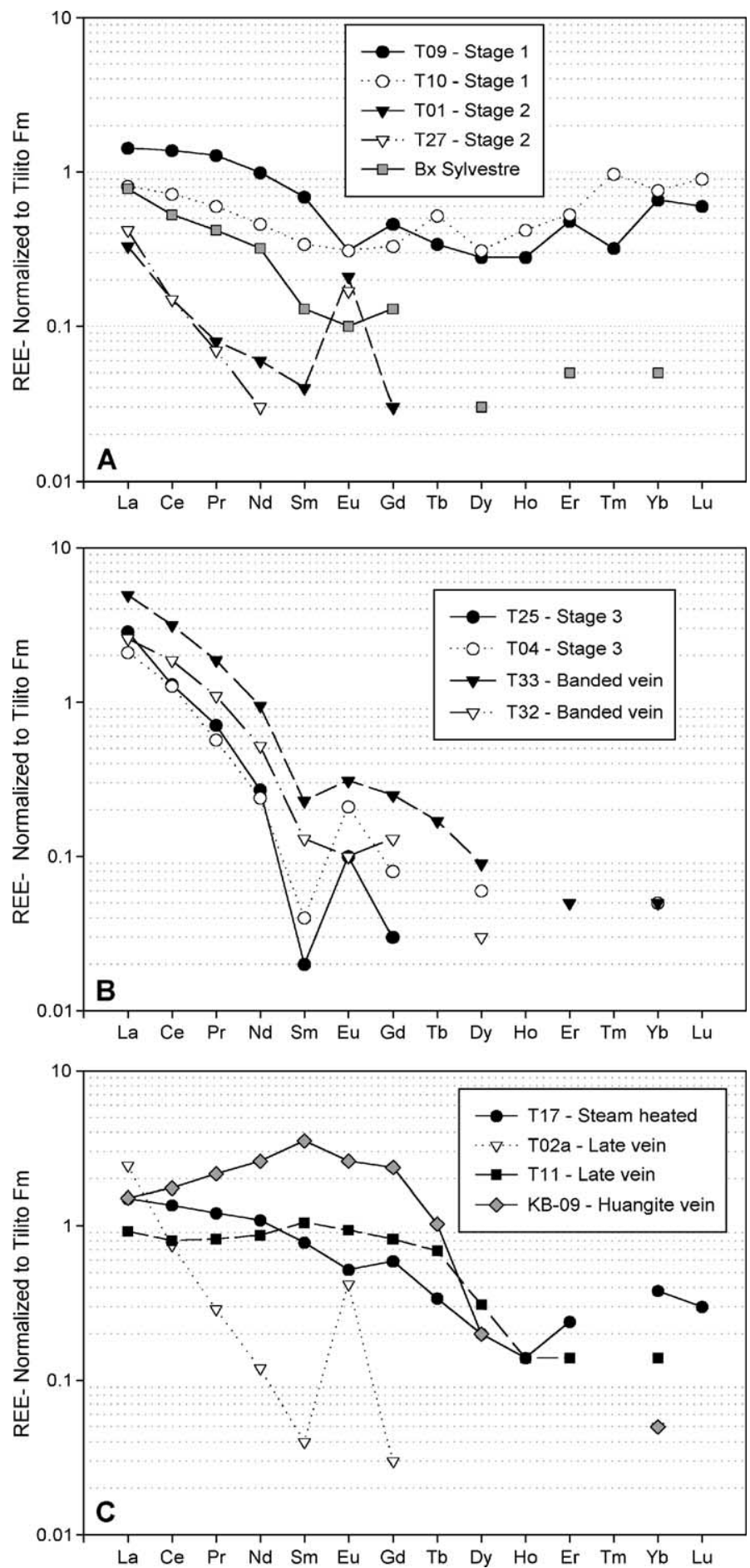

Fig. 9. REE data for all stages of Tambo alunite normalized to the average REE composition of the Tilito Formation. Individual sample numbers are given in the legend accompanying each plot. Data points below detection are not plotted. (A) Bx Sylvestre, Stage 1 and Stage 2 alunite. (B) Stage 3 and banded vein alunite. (C) Huangite-bearing vein alunite (Ca vein), steam-heated, and late-vein samples. 


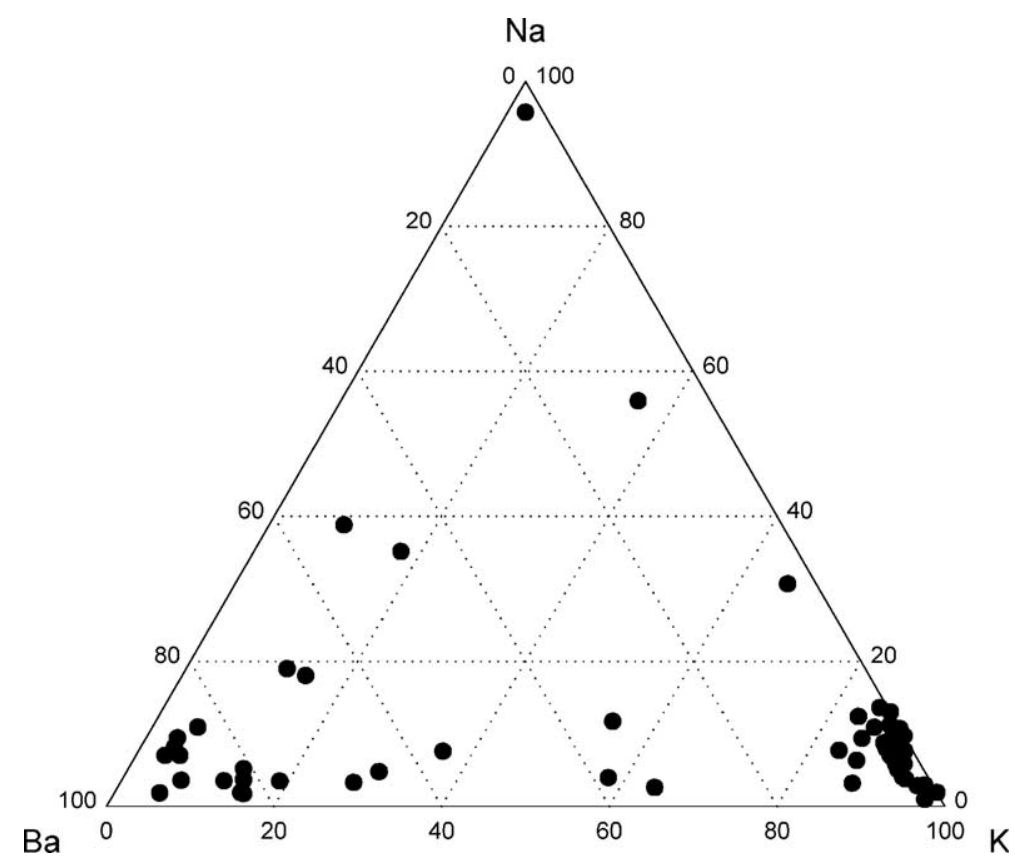

Fig. 10. Normalized K-Na-Ba compositions of Stage 2 alunite. Data points are recalculated EPMA compositions (58 analyses total from four samples).

exhibits strong fractionation in LREE, no detectable HREE, and a strong, positive Eu anomaly.

Compositions of Stage 3 and banded-vein alunite are nearly stoichiometric, with minor $\mathrm{Na}(<0.4$ a.p.f.u $)$ and trace-metal substitution. Oscillatory zoning with trace $\mathrm{PO}_{4} \pm \mathrm{Sr}$ substitution is common, and bandedvein alunite in particular has the highest $\mathrm{P}$ contents compared with those in other stages of alunite. In contrast, $\mathrm{Ca}, \mathrm{Ba}$, and $\mathrm{Pb}$ contents are low. EPMA analyses indicate almost no chemical variation across successive growth bands in the alunite veins. Stage 3 and banded-vein alunite are both enriched in LREE, with values two to five times higher than those of the host rock, but are significantly depleted in HREE. These trends are more pronounced in the banded-vein samples with $(\mathrm{La} / \mathrm{Yb})_{n}$ ratios $>100$.

Chemical data for samples of steam-heated alunite are limited because of the small grain size and relatively rare occurrence of alunite in the steam-heated alteration zone. This alunite is nearly stoichiometric, with minor $\mathrm{Na}, \mathrm{Sr}$, and P substitution. Fractionation of HREE is moderate, with minor enrichment in LREE compared with that of the host Tilito Formation. Huangite in huangite-bearing veins typically occurs as thick over- growths on alunite grains that have woodhouseitesvanbergite cores. EPMA data indicate a full range of substitution between alunite and huangite end-member compositions (Fig. 11). Oscillatory zoning between huangite and minamiite compositions occurs locally. ICP-MS results confirm very high $\mathrm{Ca}$ contents, with elevated $\mathrm{Na}$ concentrations and few trace elements. Alunite of this stage is significantly enriched in LREE and MREE relative to all other alunite types. HREE are strongly fractionated.

Geochemical data for the late veins are limited because of the fine-grained nature of the alunite. Results indicate that the mineral is chemically variable, with high $\mathrm{Sr}$ contents and locally elevated $\mathrm{Ba}, \mathrm{Pb}, \mathrm{Cu}, \mathrm{Zn}$, and $\mathrm{P}$. Sodium contents are low, and REE contents are extremely variable. One sample (T11) shows no LREE fractionation relative to hostrock values but has a significant depletion in HREE. Another sample (T02a) has a compositional variation similar to that of Stage 2 alunite, with extreme HREE fractionation and a large, positive Eu anomaly. EPMA analyses of extremely fine-grained, pseudocubic alunite from irregular veinlets indicate nearly stoichiometric compositions, minor Na substitution $(<0.2$ 


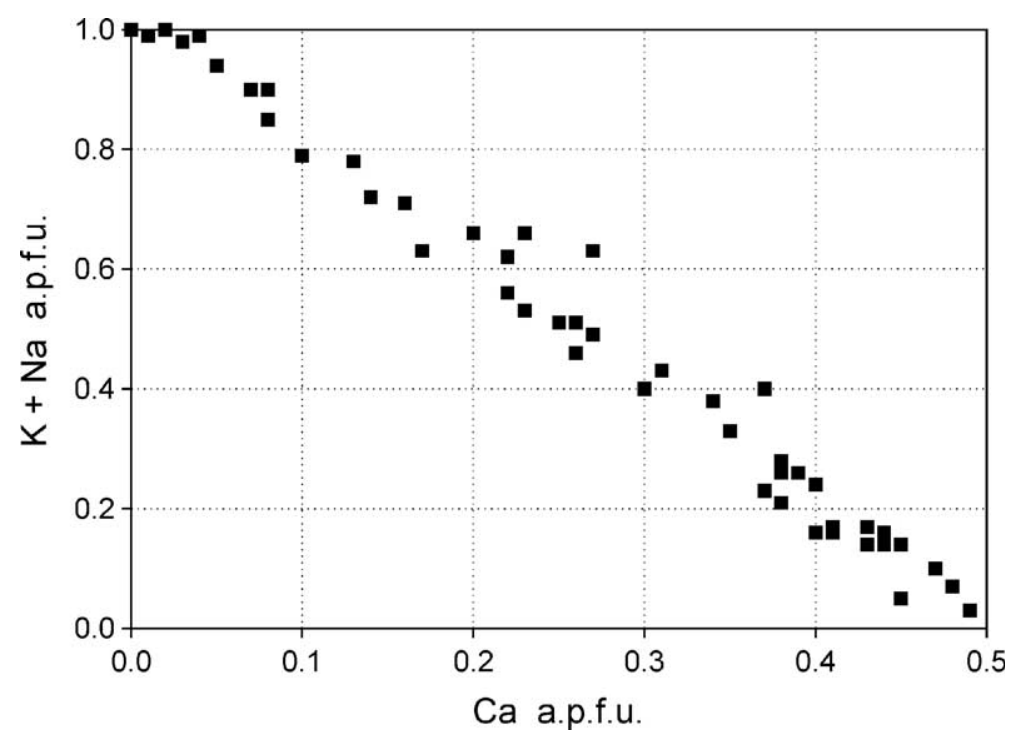

Fig. 11. Measured $\mathrm{K}+\mathrm{Na}$ versus $\mathrm{Ca}$ content of huangite-bearing vein alunite. Axes are given as atoms per formula unit (a.p.f.u.). Data taken from EPMA analyses $(n=47)$ of multiple grains in two samples, KB-09 and LN-02.

a.p.f.u.), and trace Fe. Slightly larger $(10-15 \mu \mathrm{m})$ pseudocubic grains of $\mathrm{Ca}$ - and Sr-bearing APS minerals (likely woodhouseite-svanbergite) occur intergrown with alunite and kaolinite in these veins.

\subsection{Interpretation}

Chemical data for Tambo magmatic-hydrothermal alunite are consistent with other reports of heterogeneous alunite compositions and elevated concentrations of $\mathrm{Na}, \mathrm{Ba}, \mathrm{Ca}, \mathrm{Sr}, \mathrm{PO}_{4}$, and REE in high-temperature environments (Stoffregen and Alpers, 1987; Stoffregen and Cygan, 1990; Aoki, 1991; Aoki et al., 1993; Hedenquist et al., 1994; Thompson, unpublished data). These elements typically occur as APS minerals overgrown by alunite or alunite-natroalunite (e.g., Stoffregen and Alpers, 1987; Aoki et al., 1993), as has been observed in Stage 1 samples from this study.

Few chemical data are available for alunite from other near-surface occurrences. Limited data for steam-heated alteration show significant variations (Ebert and Rye, 1997; Thompson, unpublished data), with compositions extending to the alunite and natroalunite end-members. The former is consistent with results reported in this study. Supergene alunite is generally K-rich in compar- ison with that in higher temperature occurrences, although trace-element concentrations are extremely variable, with $\mathrm{Ca}, \mathrm{Sr}, \mathrm{REE}$, and $\mathrm{PO}_{4}$ substitutions reported (Stoffregen and Alpers, 1987; Arribas et al., 1995). The elevated trace-metal concentrations for samples of late-vein alunite examined in this study are attributed to the metal content of source fluids because stable-isotope results are not consistent with the oxidation of precursor sulfides.

Few chemical analyses have been published for magmatic-steam alunite. Alunite in the Tambo banded veins, although chemically similar to that from Alunite Ridge, Utah, lacks the same degree of fine-scale, sawtooth bands of $\mathrm{PO}_{4}$ and $\mathrm{Sr}$ substitution (Cunningham et al., 1996). Substitution of Ba is also more common in Alunite Ridge samples, and is rarely detected in the Tambo banded-vein alunite.

Recent studies of the REE contents of hydrothermal fluids (Michard, 1989; Lewis et al., 1997, 1998) and of hydrothermally altered rocks (Hopf, 1993; Arribas et al., 1995; Fulignati et al., 1999) have shown that REE can be mobilized under the conditions of acid-sulfate alteration. Compared with fresh-rock equivalents, magmatic-hydrothermal alunite has been characterized by strong fractionation of HREE with respect to LREE (Arribas et al., 1995; Fulignati et al., 1999). However, compositional data for REE in the host rocks and in 
Stage 1 alunite at Tambo are not consistent with these published trends. We propose that the presence of APS inclusions and growth zones with elevated and $\mathrm{Sr}$ and $\mathrm{P}$ contents contribute to the 'capturing effect' described by Schwab et al. (1990) and allow for the incorporation of HREE into the alunite crystal structure. Similar behavior is noted for Tambo steam-heated alunite, which shows relatively minor HREE fractionation compared to host-rock values. Results are analogous to those described by Lewis et al. (1998) for altered rocks at Yellowstone National Park.

All alunite sampled from Stages 2 and 3 and the banded veins exhibits strong fractionation of HREE compared with the host-rock composition. This trend is most pronounced in the Stage 3 and banded-vein samples, whereas Stage 2 samples have comparatively lower REE concentrations. In all three stages, alunite was precipitated in open spaces (either in veins or breccia matrices), with little evidence for wallrock interaction. The chemistry of these alunite types should therefore reflect the composition of their source fluids. Experimental studies of REE partitioning between a Cl-bearing supercritical fluid and a residual melt have shown a relative enrichment in LREE compared with HREE in the vapor phase (Flynn and Burnham, 1978; Reed, 1995). No information is available for these phases at lower temperatures, but the chemical signature of the Stage 2, Stage 3 , and banded-vein alunite may reflect the composition of a HREE-depleted fluid derived from the supercritical vapor-phase. In contrast, other forms of alunite derived their REE contents from a combination of magmatic fluids and REE leached from the host rocks.

\section{Chemistry of fluid-inclusion gases}

Bulk-sample fluid-inclusion techniques are widely used for the analysis of inclusion volatiles, mainly $\mathrm{H}_{2} \mathrm{O}, \mathrm{CO}_{2}, \mathrm{CH}_{4}, \mathrm{~N}_{2}, \mathrm{H}_{2}$, and the noble gases (Shepherd and Rankin, 1998). Quadrupole mass spectrometric (QMS) analysis in particular has been applied to the identification of a large number of gases at low concentration in a variety of ore deposits and geothermal systems (e.g., Guha et al., 1990; Landis and Hofstra, 1991; Graney and Kesler, 1995b; Lindaas et al., 1998). A thorough review of this technique and its limitations is given by Graney and Kesler (1995a).

Compositions of fluid-inclusion gas in Tambo alunite were determined by QMS analysis (Landis and Rye, this volume) to characterize Stage 2 and 3 ore fluids and banded-vein alunite parental (i.e., magmatic-steam) fluids. Repeated attempts to analyze fine-grained Stage 1, steam-heated, and late-vein alunite failed to release sufficient quantities of gas. We present herein only a summary of results, and the reader is referred to Landis and Rye (this volume) for details.

Alunite samples were selected from coarsegrained assemblages and were examined petrographically prior to analysis. Stage 2 alunite, selected from the Reina vein, contains mostly small $(<10$ $\mu \mathrm{m})$, apparently primary, vapor-rich inclusions, but the results of necking are common. Other, slightly larger inclusions $(10-15 \mu \mathrm{m})$ have irregular shapes and may be secondary or pseudo-secondary in origin. These inclusions are vapor-dominant, but with more variable liquid-to-vapor ratios. Stage 3 alunite was selected from the Canto Sur deposit and contains many small $(5-10 \mu \mathrm{m})$, vapor-dominant inclusions. Banded-vein alunite, sampled from the Kimberly deposit, typically contains small, irregular, vapor-rich inclusions tightly clustered along growth zones. Repeated attempts to obtain fluid-inclusion homogenization temperatures for all three of these alunite stages were unsuccessful because of sample decrepitation.

\subsection{Results and interpretation}

Data for crush- and thermally-released gas from alunite samples are reported in Table 7. The quantity of gas released by crushing is significantly smaller than that by thermal release, and is likely the result of opening the very few and mostly larger inclusions that occur along secondary planes in the alunite. The genetic significance of these mechanically released gases is not known, but the gases probably represent mixtures of multiple pseudo-secondary generations and secondary trapping events. Thermally released gases are derived from decrepitation of the much more uniform occurrence of small primary inclusions (after removal of anomalous and secondary inclusions by crushing). These gases are generally considered to be 
Table 7

Fluid-inclusion gas chemistry data for Stage 2, Stage 3, and banded vein alunite

\begin{tabular}{|c|c|c|c|c|c|c|}
\hline \multirow{2}{*}{$\begin{array}{l}\text { Description } \\
\text { Method }\end{array}$} & \multicolumn{2}{|l|}{ Stage 2} & \multicolumn{2}{|l|}{ Stage 3} & \multicolumn{2}{|l|}{ Banded Vein } \\
\hline & Crush & Thermo & Crush & Thermo & Crush & Thermo \\
\hline Weight (g) & 8 & 8 & 6.6 & 6.6 & 7.4 & 7.4 \\
\hline $\mathrm{N}_{2}(\%)$ & 13.6131 & 0.1961 & 19.5394 & 0.5174 & 48.6233 & 20.2117 \\
\hline $\mathrm{O}_{2}(\mathrm{ppm})$ & 48 & 44 & 19 & 59 & 127 & 1045 \\
\hline $\operatorname{Ar}(p p m)$ & 4070 & 200 & 4431 & 654 & 14228 & 54992 \\
\hline $\mathrm{H}_{2}(\%)$ & 65.09 & 1.44 & 65.65 & 6.68 & 13.59 & 45.38 \\
\hline $\mathrm{H}_{2} \mathrm{O}(\%)$ & 11.3008 & 97.551 & 4.0415 & 91.1306 & 21.7247 & 29.9172 \\
\hline $\mathrm{H}_{2} \mathrm{~S}$ (ppm) & 20 & 17 & 12 & 12 & 22 & 1 \\
\hline $\mathrm{SO}_{2}(\mathrm{ppm})$ & 38 & 3 & 24 & 30 & 43 & 48 \\
\hline $\mathrm{HCl}$ (ppm) & 47 & 8 & 9 & 41 & 10 & 3 \\
\hline HF (ppm) & 313 & 2672 & 90 & 2234 & 0 & 673 \\
\hline $\mathrm{CH}_{4}(\%)$ & 0.212 & 0.014 & 0.43 & 0.083 & 0.143 & 0.5 \\
\hline $\mathrm{CO}_{2}(\%)$ & 1.637 & 0.458 & 2.173 & 0.764 & 1.141 & 3.264 \\
\hline $\mathrm{CO}(\%)$ & 7.69 & 0.045 & 7.712 & 0.52 & 20.128 & - \\
\hline He (ppm) & & & & & & 44 \\
\hline${ }^{4} \mathrm{He}(\mathrm{V})$ & 0.085718 & 1.479663 & 0.029593 & 0.945581 & 0.425582 & 0.107442 \\
\hline${ }^{4} \mathrm{He}\left(\mathrm{mol} \mathrm{g}^{-1}\right)$ & $6.872 \mathrm{e}-14$ & $1.186 \mathrm{e}-12$ & $2.876 \mathrm{e}-14$ & $9.189 \mathrm{e}-13$ & $3.689 \mathrm{e}-13$ & $9.313 \mathrm{e}-14$ \\
\hline${ }^{3} \mathrm{He}(\mathrm{cps})$ & 2.771531 & 8.834217 & 1.057146 & 9.002538 & 17.72132 & 2.350376 \\
\hline${ }^{3} \mathrm{He}\left(\mathrm{mol} \mathrm{g}^{-1}\right)$ & $3.447 \mathrm{e}-20$ & $1.099 \mathrm{e}-19$ & $1.594 \mathrm{e}-20$ & $1.357 \mathrm{e}-19$ & $2.383 e-19$ & $3.161 \mathrm{e}-20$ \\
\hline $\mathrm{R}={ }^{3} \mathrm{He} /{ }^{4} \mathrm{He}$ & $5.016 \mathrm{e}-07$ & $9.263 \mathrm{e}-08$ & $5.542 \mathrm{e}-07$ & $1.477 \mathrm{e}-07$ & $6.460 \mathrm{e}-07$ & $3.394 \mathrm{e}-07$ \\
\hline $\mathrm{R} / \mathrm{R}_{\mathrm{a}}$ & 0.3625 & 0.0669 & 0.4004 & 0.1067 & 0.4668 & 0.2452 \\
\hline${ }^{20} \mathrm{Ne}$ & 91.772 & 90.009 & 91.35 & 91.564 & 85.109 & 90.098 \\
\hline${ }^{21} \mathrm{Ne}$ & 0.29924 & 0.28346 & 0.2571 & 0.25246 & 4.23851 & 0.39388 \\
\hline${ }^{22} \mathrm{Ne}$ & 7.92907 & 9.70787 & 8.39272 & 8.1838 & 10.65245 & 9.50805 \\
\hline${ }^{21} \mathrm{Ne} /{ }^{20} \mathrm{Ne}$ & 0.0033 & 0.0031 & 0.0028 & 0.0028 & 0.0498 & 0.0044 \\
\hline${ }^{21} \mathrm{Ne} /{ }^{22} \mathrm{Ne}$ & 0.0377 & 0.0292 & 0.0306 & 0.0308 & 0.3979 & 0.0414 \\
\hline${ }^{22} \mathrm{Ne} /{ }^{20} \mathrm{Ne}$ & 0.0864 & 0.1079 & 0.0919 & 0.0894 & 0.1252 & 0.1055 \\
\hline
\end{tabular}

$\mathrm{MH}=$ magmatic-hydrothermal, $\mathrm{MS}=$ magmatic-steam, $\mathrm{a}=$ atmosphere, $\mathrm{cps}=$ counts per second. Blank fields: not detected.

representative of magmatic volatiles at the time of deposition (Graney and Kesler, 1995a). However, because of the analytical effects, the measured $\mathrm{H}_{2} \mathrm{~S}$ concentrations are considered to be a minimum value (Graney and Kesler, 1995b).

Ratios of major gas species, $\mathrm{H}_{2} \mathrm{~S}-\mathrm{SO}_{2}-\mathrm{HCl}$ (Fig. 12a), for the three alunite depositional events illustrate a distinct transition in volatiles chemistry. Stage 2 fluids are $\mathrm{H}_{2} \mathrm{~S}$-dominant $\left(\mathrm{H}_{2} \mathrm{~S}_{\mathrm{SO}} \mathrm{SO}_{2}=\sim 6\right)$, whereas magmatic-steam alunite (banded-vein sample) is characterized by a disequilibrium gas assemblage with high $\mathrm{H}_{2}$, abundant reduced carbon species, and high $\mathrm{SO}_{2}$. This chemical shift is also illustrated in Fig. 12b, with compositions recast to modeled equilibrium mole fractions at approximated temperatures and pressures for each alunite stage (using the NASA-CEA program and thermochemical data set; Gordon and McBride, 1994; McBride and Gordon, 1996; for details, see Landis and Rye, this volume).
Helium isotopes can be used as a tracer in studies of fluid flow in hydrothermal systems because isotopic compositions of $\mathrm{He}$ from atmospheric, upper-mantle, and crustal or radiogenic sources differ substantially. The atmospheric ${ }^{3} \mathrm{He} /{ }^{4} \mathrm{He}$ ratio $\left(R_{\mathrm{a}}\right)$ is $1.384 \pm 0.01 \times 10^{-6}$ (Mamyrin et al., 1969; Ozima and Podosek, 2002) and is typically used as a reference for comparison to ${ }^{3} \mathrm{He} /{ }^{4} \mathrm{He}(R)$ gas data in the form $R / R_{\mathrm{a}}$ (such that $R / R_{\mathrm{a}}=1$ for atmospheric $\mathrm{He}$ ). Mantlederived He has $R / R_{\mathrm{a}}$ values greater than 8 (Craig and Lupton, 1981; Lupton, 1983) whereas crustal ${ }^{4} \mathrm{He}$ is enriched from both radiogenic U-Th decay and nuclear spallation reactions, creating low $R / R_{\mathrm{a}}$ values of $<0.01$ in upper crustal rocks that have elevated contents of U-Th (Gerling et al., 1971; Morrison and Pine, 1955). Thermal-release ${ }^{3} \mathrm{He} /{ }^{4} \mathrm{He}$ and $R / R_{\mathrm{a}}$ in this study range from $9.3 \mathrm{e}^{-8}$ to $3.4 \mathrm{e}^{-7}$ and 0.06 to 0.25 , respectively, and clearly represent intermediate mixed values both from crustal sources and from lower crust to mantle sources with higher ${ }^{3} \mathrm{He}$. The unique 
a

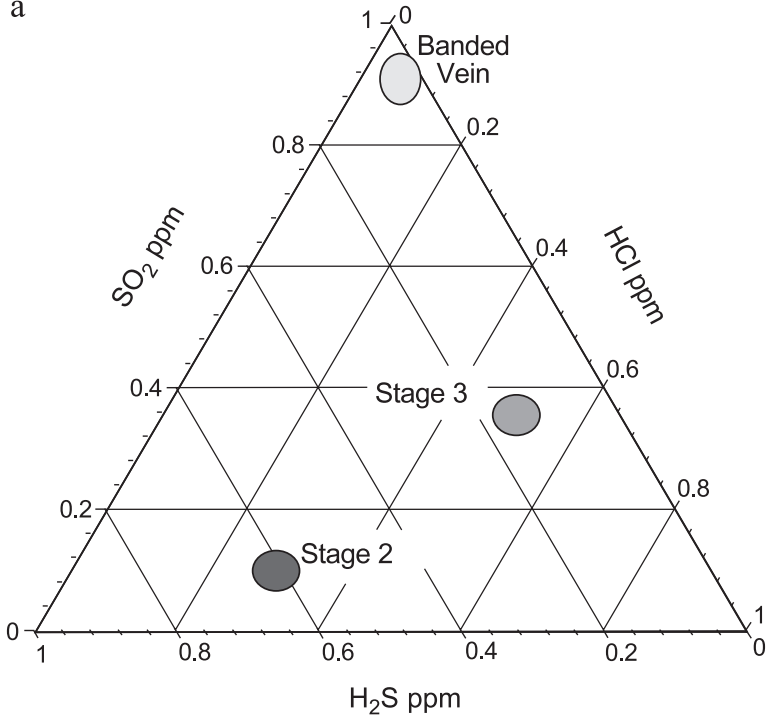

b

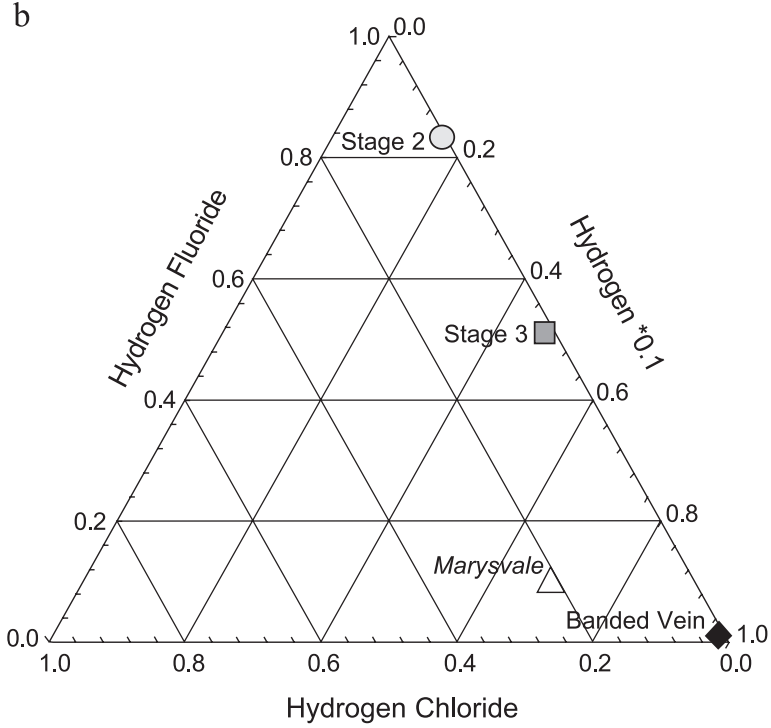

Fig. 12. (a) Ternary $\mathrm{H}_{2} \mathrm{~S}-\mathrm{SO}_{2}-\mathrm{HCl}$ data from fluid-inclusion analyses of Tambo alunite. (b) Ternary $\mathrm{HCl}-\mathrm{HF}-\mathrm{H}_{2}$ data from fluid-inclusion analyses of Tambo alunite. Methods of recalculation of mole fractions are detailed in Landis and Rye (this volume).

chemistry of the gas in these alunite samples does not allow any involvement of atmospheric gas. Stableisotope analyses indicate that only a minor amount of meteoric fluid was involved during any of these stages; hence, the volatiles and magmatic steam in particular must have been derived directly from magma, with $\mathrm{He}$ incorporated in the melt during partial melting in the lower crust or derived from condensed magmatic fluids that exchanged with crustal rocks. In particular, samples of magmaticsteam veins have the highest $R / R_{\mathrm{a}}$ values, the significance of which is discussed by Landis and Rye (this volume). We consider the highly disequilibrium gas chemistry with low He to be evidence that magmatic-steam alunite was formed from vapors that were boiled off from condensed magmatic fluids whose original gases had already been partly lost.

Similarly, the isotopic and elemental composition of Earth's Ne was different from that of the present atmosphere, and the difference can provide further indications of fluid source and the amount of crustal versus magmatic interaction. Neon isotopes are typically compared to those of end-member compositions of the atmosphere and to those of mid-oceanridge basalts (MORB), which show enrichment in ${ }^{20} \mathrm{Ne}$ and ${ }^{21} \mathrm{Ne}$ relative to ${ }^{22} \mathrm{Ne}$ (e.g., Poreda and Radicati di Brozolo, 1984; Marty, 1989). In contrast, crustal fluids typically are enriched in ${ }^{21} \mathrm{Ne}$ and ${ }^{22} \mathrm{Ne}$ relative to ${ }^{20} \mathrm{Ne}$ from crustal nucleogenic-radiogenic processes (Kennedy et al., 1990). Neon isotopic data from this study are consistent with $\mathrm{He}$ results and suggest a crustal enrichment in ${ }^{21} \mathrm{Ne}$ and ${ }^{22} \mathrm{Ne}$ relative to ${ }^{20} \mathrm{Ne}$ (Table 7).

\section{Discussion}

Fluid-inclusion and isotopic studies of several high-sulfidation deposits have indicated that magmatic fluids contribute to both alteration and mineralization within these systems (e.g., Bethke, 1984; Rye, 1993; Hedenquist and Lowenstern, 1994; Arribas, 1995; Cooke and Simmons, 2000). This magmatic component originates from the exsolution of a fluid from the melt during retrograde (or resurgent) boiling (Burnham, 1979; Burnham and Ohomoto, 1980). When the exsolved fluid reaches its solvus, the inception of aqueous immiscibility leads to the formation of low-density vapor and dense hypersaline liquid. This process is critical for the partitioning of ore metals from the melt to the hydrothermal system (Candela and Piccoli, 1995; Williams et al., 1995; Heinrich et al., 1999). The vapor phase will rise to shallow depths and condense, and the ensuing low-pH 
fluids will react with wallrocks. Spent fluids will either discharge at surface as volcanic fumaroles, or be absorbed into groundwater. The dense, hypersaline liquid remains at depth and is recorded as saline fluid inclusions in intrusive rocks and porphyry ore deposits (Hedenquist and Lowenstern, 1994 and references therein), or becomes part of later epithermal mineralization (Rye, 1993). As magmatic fluids rise through the crust, they typically undergo phase separation at the transition from brittle to plastic behavior in the lithosphere (Fournier, 1999). This transition typically occurs at about 370 to $400{ }^{\circ} \mathrm{C}$ in continental hydrothermal systems (Fournier, 1999). Abrupt changes in the pressure regime across this transition zone are thought to be responsible for porphyry $\mathrm{Cu}$ mineralization in several systems (e.g., Fournier, 1967; Gustafson and Hunt, 1975; Cunningham, 1978), and for porphyry $\mathrm{Au}$ mineralization (Muntean and Einaudi, 2000). Similarly, several authors have related epithermal mineralization to the escape of magmatic fluids into hydrostatically pressured hydrothermal systems (e.g., Fournier, 1987; Rye, 1993; Deen et al., 1994; Hedenquist et al., 1994). In the following discussion, we examine the role of magmatic fluids in the Tambo high-sulfidation system, and the nature of magmatic-steam processes.

\subsection{Role of magmatic fluids in alunite deposition}

It is generally accepted that hypogene acid-sulfate alteration, characterized by the assemblage alunite+ quartz + kaolinite \pm pyrite, results from acidic fluids that are generated by the condensation of magmatic volatiles enriched in $\mathrm{SO}_{2}, \mathrm{HCl}$, and $\mathrm{HF}$. The disproportionation of $\mathrm{SO}_{2}$, beginning at about $400{ }^{\circ} \mathrm{C}$, and the dissociation of $\mathrm{HCl}$ and $\mathrm{HF}$ at temperatures below about $300-350{ }^{\circ} \mathrm{C}$ (Holland, 1965; Hemley et al., 1969) create solutions that are sufficiently acidic to leach most components from the host rock, leaving a vuggy quartz residue. The progressive neutralization of these fluids by reaction with wallrock forms successive alteration envelopes of acid-sulfate, advanced argillic, argillic, and propylitic assemblages outward from the main fluid conduit (e.g., Steven and Ratté, 1960). Stable-isotope evidence indicates that the degree of meteoric water interaction during hypogene acid-sulfate alteration is variable. At the Julcani deposit in Peru, for example, the condensed liquids responsible for magmatic hydrothermal alunite were almost entirely of magmatic origin (Deen et al., 1994). A large component of magmatic fluid was also present at Rodalquilar (Arribas et al., 1995). By contrast, the fluids responsible for magmatic hydrothermal alunite in many other high-sulfidation deposits had a much more extensive component of meteoric water (e.g., Summitville, Rye et al., 1990; Nansatsu, Hedenquist et al., 1994; Pueblo Viejo, Venneman et al., 1993).

Examples of magmatic contributions to the nearsurface steam-heated environment are fewer. Steamheated alunite forms from aqueous sulfate created by the oxidation of $\mathrm{H}_{2} \mathrm{~S}$ at or above the water table (Schoen et al., 1974). The fluids responsible for this alunite typically have a meteoric isotopic signature (e.g., Rye et al., 1992; Ebert and Rye, 1997); however, deuterium enrichment (10-20\%o) is common in steamheated fluids from active geothermal systems. This enrichment can be attributed to the effects of either subsurface boiling or evaporation (Truesdell et al., 1977; Henley and Stewart, 1983). However, magmatic fluids with low $\delta \mathrm{D}$ values have been documented in shallow steam-heated environments (Rye et al., 1992).

Shallow late-stage alteration at Tambo also involved a large magmatic fluid component. Stable isotopic data indicate that the parental fluids responsible for this late-stage alteration were mixtures ranging from nearly pure magmatic fluids with low $\delta \mathrm{D}$ (either magmatic steam or condensed magmatic vapor) to dominantly meteoric water. The variability in trace-element contents for alunite of this stage is attributed to different magmatic and meteoric fluid mixtures in the shallow epithermal environment.

Overall, there is a strong magmatic fluid component to parental fluids for all alunite types at the Tambo deposit, even in near-surface and late-stage occurrences. Even the groundwater at Tambo seems to have had a substantial component of condensed magmatic fluid. These fluids effectively displaced or mixed with meteoric groundwaters. We attribute the dominance of magmatic fluids at Tambo to climatic and physiographic characteristics specific to the El Indio-Pascua belt, as detailed in Bissig (2001) and Deyell et al. (2004). The region was dominated by extensive sub-planar surfaces that were incised during regional erosion starting in the late Miocene (Bissig, 2001). The near-surface fluid dynamics in this setting 
(Bissig, 2001), combined with arid conditions, presumably limited the availability of meteoric water in the upper part of the Tambo system.

\subsection{Role of magmatic fluids in mineralization}

Although the consensus is that the fluids responsible for high-sulfidation deposits are of magmatic origin (e.g., Rye et al., 1992; Hedenquist and Lowenstern, 1994; Arribas, 1995; Cooke and Simmons, 2000), there is considerable debate about the nature of these fluids, and particularly about the relative contributions of vapor versus hypersaline liquid to the formation of $\mathrm{Au}, \mathrm{Ag}$, and $\mathrm{Cu}$ mineralization. Several authors have argued that mineralization is a two-stage process involving both vapor and later saline magmatic fluids (e.g., Stoffregen, 1987; Rye, 1993; Arribas, 1995). On the basis of the results of fluid-inclusion and isotopic studies of several highsulfidation deposits, three possible ore-fluid types were summarized by Cooke and Simmons (2000):

(a) Low-salinity, supercritical magmatic fluids which cool to a single-phase liquid before boiling at shallow levels and which transport $\mathrm{Au}$ and possibly $\mathrm{Cu}$ as $\mathrm{H}_{2} \mathrm{~S}$ complexes (Loucks and Mavrogenes, 1999).

(b) Metal-bearing, acidic brines, derived from the second boiling of magmatic fluids, transport $\mathrm{Au}$ and $\mathrm{Cu}$ presumably largely as chloride complexes (Henley, 1973).

(c) Reduced magmatic vapors (the counterpart of the brines from the second boiling of magmatic fluids) that transport $\mathrm{Au}$ and $\mathrm{Cu}$ as volatile sulfide, bisulfide, or chloride complexes (Henley, 1973; Seward, 1973; Gibert et al., 1998).

Recently, Muntean and Einaudi (2001) proposed that high-sulfidation gold ore at La Pepa (Maricunga belt) was formed simultaneously with quartz-alunite alteration by the condensation of a moderately saline, supercritical fluid that was later flashed, from below the brittle-ductile transition, into shallow meteoric waters.

Recent studies of metal fractionation between magmatic brines and vapors, and evidence from fluid and melt inclusions, indicate that magmatic vapors have the capacity to transport metals such as $\mathrm{Cu}$ and $\mathrm{Au}$ for high-sulfidation mineralization, particularly at high pressures (Lowenstern et al., 1991; Heinrich et al., 1992; Shinohara, 1994; Audétat et al., 1998; Heinrich et al., 1999; Ulrich et al., 1999; Archibald et al., 2001). At Tambo, Stage 2 alunite and ore resulted from $\mathrm{H}_{2} \mathrm{~S}-$ dominant, low-salinity magmatic vapor (this study; Jannas et al., 1999). There is no evidence for a hypersaline fluid component; nearly all fluid inclusions measured by Jannas (1995) contain $<4$ wt.\% NaCl equivalent. We infer that $\mathrm{Au}$ was transported in a magmatic vapor phase, either as volatile species (e.g., $\mathrm{AuS}_{(\mathrm{g})}$ ) or as bisulfide complexes. The high Te content of the mineralizing assemblage is also consistent with vapor-phase transport (Cooke and McPhail, 2000). The Stage 2 high-sulfidation mineralization most likely precipitated from condensed magmatic vapor that rose from the brittle-ductile transition and was responsible for the earlier acid-sulfate alteration.

The nature of Stage 3 ore fluids is less clear, but again there is no fluid-inclusion or gas-chemistry evidence for a hypersaline brine component. Stage 3 fluids were more vapor-rich magmatic fluids and more oxidized $\left(\mathrm{SO}_{2}\right.$-rich) than those responsible for Stage 2 $\mathrm{Au}$ deposition. There are two viable scenarios for these fluids: (1) they may have been derived as vapor directly from a magma, or (2) they may have been derived as flashed liquids from below the brittle-ductile transition (much as suggested by Muntean and Einaudi, 2001). The latter scenario is suggested by the gas-chemistry data, in particular the lack of $\mathrm{He}$ in fluid inclusions within the alunite of magmatic-steam origin (Landis and Rye, this volume) and the lack of sawtooth banding in the trace-element pattern of this type of alunite. Presumably, some Au was transported in these fluids as a chloride complex (Archibald et al., 2001).

\subsection{Origin of magmatic-steam alunite}

The magmatic-steam environment was initially defined by Rye et al. (1992) on the basis of data for veins of coarsely crystalline alunite at Marysvale, Utah (Cunningham et al., 1984). This alunite is characterized by disequilibrium $\delta^{34} \mathrm{~S}$ but near-equilibrium $\delta^{18} \mathrm{O}$ and magmatic $\delta \mathrm{D}$ values. Documented occurrences of this type of alunite are rare, and magmatic-steam processes are poorly understood. Magmatic steam was important at the Tambo deposit, however, because of its abundance and association with Stage 3 ore. Stable- 
isotope and fluid-inclusion data from this study and that of Landis and Rye (this volume) help to characterize the magmatic-steam environment. Important observations are summarized below.

(a) Like the Marysvale magmatic-steam alunite, the inclusion fluids for the Tambo alunite have much lower $\mathrm{H}_{2} \mathrm{~S} / \mathrm{SO}_{2}$ than inclusion fluids in magmatic-hydrothermal alunite.

(b) Alunite of magmatic-steam origin at Tambo is also characterized by having nearly constant $\delta^{34} \mathrm{~S}$ values that are close to the value of the bulk $\mathrm{S}$ in the magma (Rye et al., 1992). Given that sulfur-isotope equilibrium between aqueous sulfate and sulfide is obtained quickly at high temperature (Ohmoto and Lasaga, 1982), a rapid rate of vapor ascent and mineral deposition is required once the fluids leave their source (Rye et al., 1992; Rye, 1993).

(c) Inclusion fluids of both the Marysvale and Tambo magmatic-steam alunite are vapor-rich.

(d) Tambo magmatic-steam alunite is significantly enriched in LREE and strongly fractionated in HREE compared with the host rock. These data may reflect REE partitioning into the vapor phase (e.g., Flynn and Burnham, 1978; Reed, 1995).

(e) Magmatic-steam alunite formed late in the development of the Tambo hydrothermal system. A similar transition from early magmatichydrothermal to late magmatic-steam processes has also been documented at the Red Mountain deposit, Colorado (Bove et al., 1990; Rye et al., 1992).

(f) Two important differences between the Marysvale and Tambo magmatic-steam alunite are that the fluid inclusions at Tambo are depleted in $\mathrm{He}$ and they do not contain the sawtooth traceelement patterns observed for Marysvale alunite. This pattern for Marysvale alunite is thought to be related directly to magmatic degassing (Cunningham et al., 1996; Rye, this volume; Landis and Rye, this volume). The lack of He in the Tambo magmatic-steam alunite indicates that the magmatic vapor was already degassed and thus could not have come directly from a melt.

The parental fluids for the magmatic-steam alunite at Tambo were most likely derived by flashing, due to sudden decompression, of condensed magmatic fluids that accumulated below the brittle-ductile transition near a shallow magma. This scenario is similar to that proposed by Muntean and Einaudi (2001) for highlevel $\mathrm{Au}$ mineralization at La Pepa, Chile. After decompression of the system, the ensuing vapor fluids were $\mathrm{SO}_{2}$-dominant because of the effect of high temperature and low pressure on the gas equilibria of the sulfur species (Gerlach, 1993). Prior loss of $\mathrm{H}_{2} \mathrm{~S}$ to the vapor phase may have also increased the oxidation state of the residual liquids.

\section{Summary}

Detailed argon-age, stable-isotope, fluid-inclusion gas, and geochemical analyses of alunite from the Tambo deposit, coupled with the geological framework determined by Jannas et al. (1999), have allowed a study of shallow-level magmatic-hydrothermal processes. Hydrothermal activity at Tambo was characterized by multiple stages of alteration and two mineralizing events related to episodic magmatic activity over a period of at least $4 \mathrm{my}$. We have focused on the characteristics of alunite within this deposit to gain insight into the nature of parental fluids in magmatic-hydrothermal, magmatic-steam, steam-heated, and apparent supergene environments. Results from this study have shown:

(1) There is a strong magmatic signature to all stages and environments of acid alteration in the Tambo area, even in the near-surface steam-heated environment and at shallow levels during the final stages of the hydrothermal system, in what is easily mistaken for supergene alteration. The meteoric water component in fluids of all stages of alteration is ${ }^{18} \mathrm{O}$-enriched. The isotopic data for fluids reflect unusually arid conditions during mineralization.

(2) Magmatic vapor-phase transport of Au is inferred for both Stage 2 and Stage 3 mineralization.

(3) The fluids responsible for both alteration and the associated Stage 2 and 3 mineralization evolved from high-temperature magmatic vapor-bearing fluids that had different origins for each stage. The vapor responsible for the deposition of magmatic-hydrothermal alunite and Stage 2 mineralization was derived as a long-standing, $\mathrm{H}_{2} \mathrm{~S}$-rich plume that rose above the brittle- 
ductile transition. This vapor was derived from the "second boiling" of the magmatic fluids. The vapor responsible for magmatic-steam alunite and Stage 3 mineralization was $\mathrm{SO}_{2}$-rich and probably was derived from the flashing of partly degassed and oxidized saline fluids beneath the brittle-ductile transition. The transition from magmatic-hydrothermal to magmatic-steamdominated processes probably reflects sudden decreases in pressure in the hydrothermal system.

\section{Acknowledgements}

This paper stems from a $\mathrm{PhD}$ project undertaken by the lead author at the University of British Columbia. Funding was provided by Barrick Gold and Barrick Chile, with additional support from NSERC. This study would not have been possible without the expertise and knowledge of Barrick geologists, particularly R. Guerra and the exploration staff at Km. 34, and the Tambo mine staff. Discussions and assistance provided by K. Heather, D. Heberlein, N. Rojas, and R. Jannas are greatly appreciated. PIMA instrumentation and expertise was provided by A. Thompson and Petrascience Consulting. C. Kester and M. Raudsepp are thanked for their technical assistance. This manuscript benefited greatly from early reviews and comments by S. Ebert, J. Thompson, J. Hedenquist, P. Bethke, A. Hofstra, L. Groat, and J. Richards. We also thank the Chemical Geology reviewers, K. Heather and G. Arehart, and editors for their constructive comments. [PD]

\section{References}

Aoki, M., 1991. Mineralogical features and genesis of alunite solid solution in high temperature magmatic-hydrothermal systems. J. Geol. Surv. Jpn. 277, 31-32.

Aoki, M., Comsti, E.C., Lazo, F.B., Matsuhisa, Y., 1993. Advanced argillic alteration and geochemistry of alunite in an evolving hydrothermal system at Baguio, northern Luzon, Philippines. Resour. Geol. 43, 155-164.

Archibald, S.M., Migdisov, A.A., Williams-Jones, A.E., 2001. The stability of Au-chloride complexes in water vapor at elevated temperature and pressures. Geochim. Cosmochim. Acta 65, $4413-4423$
Arribas Jr., A., 1995. Characteristics of high sulfidation epithermal deposits, and their relation to magmatic fluids. In: Thompson, J.F.H.Magmas, Fluids, and Ore Deposits. Mineral. Assoc. Can. Short Course vol. 23. , pp. 419-454.

Arribas Jr., A., Cunningham, C.G., Rytuba, J.J., Rye, R.O., Kelly, W.C., McKee, E.H., Podwysocky, M.H., Tosdal, R.M., 1995. Geology, geochronology, fluid inclusions, and stable isotope geochemistry of the Rodalquilar $\mathrm{Au}$ alunite deposit, Spain. Econ. Geol. 90, 795-822.

Audétat, A., Günther, D., Heinrich, C.A., 1998. Formation of magmatic-hydrothermal ore deposit: Insights with LA-ICP-MS analysis of fluid inclusions. Science 279, 2091-2094.

Barazangi, M., Isacks, B.L., 1976. Spatial distribution of earthquakes and subduction of the Nazca Plate beneath South America. Geology 4, 686-692.

Beane, R.E., 1991. Deposit correlations in the El Indio Belt, Chile: mineral paragenesis, fluid inclusions, and sulfur isotopes. Barrick Gold and Barick Chile, Internal company report, La Serena, Chile.

Bennet, R.E., 1995. A combined hydrothermal alteration study and exploration target evaluation of the Tambo mining district, El Indio mineral belt, Region IV, Chile. Companià Minera San José, Internal company report, Chile.

Bethke, P.M., 1984. Controls on base- and precious-metal mineralization in deeper epithermal environments. U.S. Geol. Surv. Open-File Rep., 84-890.

Bissig, T., 2001. Metallogenesis of the Miocene El Indio-Pascua gold-silver-copper belt, Chile/Argentina: Geodynamic, geomorphological and petrochemical controls on epithermal mineralization. Ph.D. thesis, Queen's University, Kingston, Canada.

Bove, D.J., Rye, R.O., Hon, K., 1990. Evolution of the Red Mountain alunite deposits, Lake City, Colorado. U.S. Geol. Surv. Open-File, 90-102.

Burnham, C.W., 1979. Magmas and hydrothermal fluids. In: Barnes, H.L. (Ed.), Geochemistry of Hydrothermal Ore Deposits. Wiley, New York, pp. $71-136$.

Burnham, W.C., Ohomoto, H., 1980. Late-stage processes of felsic magmatism. Min. Geol. Spec. Issue 8, 1-11.

Candela, P.A., Piccoli, P.M., 1995. Model ore-metal partitioning from melts into vapor and vapor-brine mixtures. In: Thompson, J.F.H. (Ed.), Magmas, Fluids, and Ore Deposits, Mineral. Assoc. Can. Short Course vol. 23. , pp. 101-127.

Clayton, R.N., Mayeda, T.K., 1963. The use of bromine pentafluoride in the extraction of oxygen from oxides and silicates for isotopic analysis. Geochim. Cosmochim. Acta 27, 43-52.

Cooke, D.R., McPhail, D.C., 2000. Epithermal Au-Ag-Te mineralization, Acupan, Baguio District, Philippines: Numerical simulations of mineral deposition. Econ. Geol. 96, 109-131.

Cooke, D.R., Simmons, S.F., 2000. Characteristics and genesis of epithermal gold deposits. In: Hagemann, S.G., Brown, P.E. (Eds.), Gold 2000, Rev. Econ. Geol. vol. 13, pp. 221-244.

Craig, H., 1961. Isotopic variations in meteoric waters. Science 133, $1702-1703$.

Craig, H., Lupton, J.E., 1981. ${ }^{3} \mathrm{He}$ and mantle volatiles in the ocean and the ocean crust. In: Emiliani, C. (Ed.), The Sea; Ideas and Observations on Progress in the Study of the Seas. Wiley, New York, pp. $391-428$. 
Cunningham, C.G., 1978. Pressure gradients and boiling as mechanisms for localizing ore in porphyry systems. U.S. Geol. Surv. J. Res. 6, 745-754.

Cunningham, C.G., Rye, R.O., Steven, T.A., Mehnert, H.H., 1984. Origins and exploration significance of replacement and veintype alunite deposits in the Marysvale volcanic field, west central Utah. Econ. Geol. 79, 50-71.

Cunningham, C.G., Rye, R.O., Bethke, P.M., Logan, M.A.V., 1996. Formation of coarse-grained vein alunite by degassing of an epizonal stock. Chapman Conference on Crater Lakes, Terrestrial Degassing and Hyper-Acid Fluids in the Environment, Extended Abstracts. Sept. 4-9, 1996, Crater Lake, Oregon. Am. Geophys. Union, Washington, DC, pp. 27.

Deen, J.A., Rye, R.O., Munoz, J.L., Drexler, J.W., 1994. The magmatic-hydrothermal system at Julcani, Peru: evidence from fluid inclusions and hydrogen and oxygen isotopes. Econ. Geol. 89, 1924-1938.

Deyell, C.L., 2001. Alunite and high sulfidation $\mathrm{Au}-\mathrm{Ag}-\mathrm{Cu}$ mineralization in the El Indio-Pascua Belt, Chile-Argentina, $\mathrm{PhD}$ thesis, Univ. British Columbia, Vancouver, Canada.

Deyell, C.L., Bissig, T., Rye, R.O., 2004. Isotopic evidence for magmatic-dominated epithermal processes in the El IndioPascua $\mathrm{Au}-\mathrm{Cu}-\mathrm{Ag}$ belt and relationship to geomorphologic settings. Econ. Geol. Spec. Publ. 11, 55-73.

Ebert, S.W., Rye, R.O., 1997. Secondary precious metal enrichment by steam-heated fluids in the Crowfoot-Lewis hotspring goldsilver deposit and relation to paleoclimate. Econ. Geol. 92, $578-600$.

Flynn, F.R., Burnham, C.W., 1978. An experimental determination of rare earth partition coefficients between a chloride-containing vapor phase and silicate melts. Geochim. Cosmochim. Acta 42, 685-701.

Fournier, R.O., 1967. The porphyry copper deposit exposed in the Liberty open-pit mine near Ely, Nevada: Part I. Syngenetic formation. Econ. Geol. 62, 57-81.

Fournier, R.O., 1987. Conceptual models of brine evolution in magmatic-hydrothermal systems. U.S. Geol. Surv. Prof. Pap. 1350 (2), 1487-1506.

Fournier, R.O., 1999. Hydrothermal processes related to movement of fluid from plastic into brittle rock in the magmatic-hydrothermal environment. Econ. Geol. 94, 1193-1212.

Fulignati, P., Gioncada, A., Sbrana, A., 1999. Rare-earth element behaviour in the alteration facies of the active magmatic-hydrothermal systems of Vulcano (Aeolian Islands, Italy). J. Volcanol. Geotherm. Res. 88, 325-342.

Gerlach, T.M., 1993. Oxygen buffering of Kilauea volcanic gases and the oxygen fugacity of Kilauea basalt. Geochim. Cosmochim. Acta 57, 795-814.

Gerling, E.K., Mamyrin, B.A., Tolstikhin, I.N., 1971. Helium isotope composition in some rocks. Geochem. Int. 8, 755-761.

Gieseman, A., Jager, H.J., Norman, A.L., Krouse, H.R., Brand, W.A., 1994. On-line sulfur-isotope determination using and elemental analyzer coupled to a mass spectrometer. Anal. Chem. 66, 2816-2819.

Gibert, F., Pascal, M.L., Pichavant, M., 1998. Gold solubility and speciation in hydrothermal solutions: Experimental study of the stability of hydrosulfide complex of gold $\left(\mathrm{AuHS}^{\circ}\right)$ at 350 to $450{ }^{\circ} \mathrm{C}$ and 500 bars. Geochim. Cosmochim. Acta 62, 2931-2947.

Giggenbach, W.F., 1992. Magma degassing and mineral deposition in hydrothermal systems along convergent plate boundaries. Econ. Geol. 87, 1927-1944.

Godfrey, J.D., 1962. The deuterium content of natural waters and other substances. Geochim. Cosmochim. Acta 27, 43-52.

Gordon, S., McBride, B.J., 1994. Computer program for calculation of complex chemical equilibrium compositions and applications: I. Analysis. NASA Ref. Publ. 1311, 55 pp.

Graney, J.R., Kesler, S.E., 1995a. Gas composition of inclusion fluid in ore deposits: is there a relation to magmas? In: Thompson, J.F.H. (Ed.), Magmas, Fluids, and Ore Deposits, Mineral. Assoc. Can. Short Course, vol. 23, pp. 221-246.

Graney, J.R., Kesler, S.E., 1995b. Factors affecting gas analysis of inclusion fluid by quadrupole mass spectrometry. Geochim. Cosmochim. Acta 59, 3977-3986.

Guha, J., Lu, L.Z., Gagnon, M., 1990. Gas composition of fluid inclusions using solid probe mass spectrometry and its application to study of mineralizing processes. Geochim. Cosmochim. Acta 54, 553-558.

Gustafson, L.B., Hunt, J.P., 1975. The porphyry copper deposit at El Salvador, Chile. Econ. Geol. 70, 857-912.

Heather, K.B., Diaz, D., 2000. El Indio-Tambo District regional geological mapping program 1997-1999, Barick Chile, Internal company report, 2 Vol., La Serena, Chile.

Hedenquist, J.W., Lowenstern, J.B., 1994. The role of magmas in the formation of hydrothermal ore deposits. Nature 370, 519-527.

Hedenquist, J.W., Matsuhisa, Y., Izawa, E., White, N.C., Giggenbach, W.F., Aoki, M., 1994. Geology, geochemistry, and origin of high sulfidation $\mathrm{Cu}-\mathrm{Au}$ mineralization in the Nansatsu District, Japan. Econ. Geol. 89, 1-30.

Heinrich, C.A., Ryan, C.G., Mernagh, T.P., Eadington, P.J., 1992. Segregation of ore metals between magmatic brine and vapor: a fluid inclusion study using PIXE microanalysis. Econ. Geol. 87, $1566-1583$.

Heinrich, C.A., Gunther, D., Audétat, A., Ulrich, T., Frischknecht, R., 1999. Metal fractionation between magmatic brine and vapor, determined by microanalysis of fluid inclusions. Geology $27,755-758$.

Hemley, J.J., Hostetler, P.B., Gude, A.J., Mountjoy, W.T., 1969. Some stability relations of alunite. Econ. Geol. 64, 599-612.

Henley, R.W., 1973. Solubility of gold in hydrothermal chloride solutions. Chem. Geol. 11, 73-87.

Henley, R.W., Stewart, M.K., 1983. Chemical and isotopic changes in the hydrology of the Tauhara geothermal field due to exploitation at Wairakei. J. Volcanol. Geotherm. Res. 15, 285-314.

Holland, H.D., 1965. Some applications of thermochemical data to problems of ore deposits: II. Mineral assemblages and the compositions of ore-forming fluids. Econ. Geol. 60, $1101-1166$.

Hopf, S., 1993. Behavior of rare earth elements in geothermal systems of New Zealand. J. Geochem. Explor. 47, 333-357.

Jambor, J.L., 1999. Nomenclature of the alunite supergroup. Can. Mineral. 37, 1323-1341. 
Jannas, R.R., 1995. Reduced and oxidized high sulfidation deposits of the El Indio deposit, Chile. PhD thesis, Harvard Univ., Cambridge, MA.

Jannas, R.R., Bowers, T.S., Petersen, U., Beane, R.E., 1999. Highsulfidation deposit types in the El Indio District, Chile. In: Skinner, B.J. (Ed.), Geology and Ore Deposits of the Central Andes, Soc. Econ. Geol. Spec. Pub., vol. 7, pp. 27-59.

Kennedy, B.M., Hiyagon, H., Reynolds, J.H., 1990. Crustal neon: a striking uniformity. Earth Planet. Sci. Lett. 98, 277-286.

Kornexl, B.E., Gehre, M., Höfling, R., Werner, R.A., 1999. On-line $\delta^{18} \mathrm{O}$ measurement of organic and inorganic substances. Rapid Commun. Mass Spectrom. 13, 1685-1693.

Landis, G.P., Hofstra, A.H., 1991. Fluid inclusion gas chemistry as a potential mineral exploration tool: Case studies from Creede, CO, Jerrit Canyon, NV, Coeur d'Alene district, ID and MT, southern Alaska epithermal veins, and mid-continent MVT's. J. Geochem. Explor. 42, 25-60.

Landis, G.P., Rye, R.O., 2005. Characterization of gas chemistry and noble-gas isotopic ratios of inclusion fluids in magmatichydrothermal environments. Chem. Geol. 215, 155-184. (this volume).

Lewis, A.J., Palmer, M.R., Sturchio, N.C., Kemp, A.J., 1997. The rare earth element geochemistry of acid-sulphate and acid-sulphatechloride geothermal systems from Yellowstone National Park, Wyoming, USA. Geochim. Cosmochim. Acta 61, 695-706.

Lewis, A.J., Komminou, A., Yardley, B.W.D., Palmer, M.R., 1998. Rare earth element speciation in geothermal fluids from Yellowstone National Park, Wyoming, USA. Geochim. Cosmochim. Acta 62, 657-663.

Li, G., Peacor, D.R., Essene, E.J., Brosnahan, D.R., Beane, R.E., 1992. Walthierite and huangite, two new minerals of the alunite group from the Coquimbo region, Chile. Am. Mineral. 77, 1275-1284.

Lindaas, S.E., Chomiak, B.A., Campbell, A.R., Norman, D.I., 1998. Enargite-hosted fluid inclusion gases from the Lepanto, Philippines, high-sulfidation $\mathrm{Cu}-\mathrm{Au}$ deposit. Geol. Soc. Am. Abstr. Programs 30 (7), 20.

Lottermoser, B.J., 1992. Rare earth elements and hydrothermal ore formation processes. Ore Geol. Rev. 7, 25-41.

Loucks, R.R., Mavrogenes, J.A., 1999. Gold solubility in supercritical hydrothermal brines measured in synthetic fluid inclusions. Science 284, 2159-2163.

Lowenstern, J.B., Mahood, G.A., Rivers, M.L., Sutton, S.R., 1991. Evidence for extreme partitioning of copper into a magmatic vapor phase. Science 257, 1405-1409.

Lupton, J.E., 1983. Terrestrial inert gases: isotope tracer studies and clues to primordial components in the mantle. Ann. Rev. Earth Sci. $11,371-414$.

Maksaev, V., Moscoso, R., Mpodozis, C., Nasi, C., 1984. Las unidades volcánicas y plutonicas del cenozoico superior en la Alta Cordillera del Norte Chico $\left(29^{\circ}-31^{\circ} \mathrm{S}\right)$ : Geología, alteración hidrothermal y mineralisacion. Rev. Geol. Chile 21, 11-51.

Mamyrin, B.A., Anufriev, G.S., Kamenski, I.L., Tolstikhin, I.N., 1969. Determination of the isotopic composition of atmospheric helium. Geochem. Int. 7, 498-505.

Martin, M., Clavero, J., Mpodozis, C., 1995. Estudio geologico regional del Franja El Indio, Cordillera de Coquimbo. Servicio
National de Geología y Minería, Santiago, Chile. Registered report IR-95-06, $232 \mathrm{pp}$.

Martin, M.W., Clavero, J.R., Mpodozis, C.M., 1997. Eocene to Late Miocene magmatic development of the El Indio belt, $\sim 30{ }^{\circ} \mathrm{S}$, north-central Chile. Congreso Geol. Chileno, VIII, Concepción Chile, Actas vol. 1. , pp. 149-153.

Martin, M.W., Clavero, J.R., Mpodozis, C., 1999. Late Paleozoic to Early Jurassic tectonic development of the high Andean Principal Cordillera, El Indio Region, Chile (29-30 $\mathrm{S})$. J. South Am. Earth Sci. 12, 33-49.

Marty, B., 1989. Neon and xenon isotopes in MORB: implications for the earth-atmosphere evolution. Earth Planet. Sci. Lett. 94, $45-56$.

McBride, B.J., Gordon, S., 1996. Computer program for calculation of complex chemical equilibrium compositions and applications: II. Users manual and program description. NASA Ref. Publ., 1311.

Michard, A., 1989. Rare earth element systematics in hydrothermal fluids. Geochim. Cosmochim. Acta 53, 745-750.

Morrison, P., Pine, J., 1955. Radiogenic origin of the helium isotopes in rock. N.Y. Acad. Sci., Ann. 62, 71-92.

Muntean, J.L., Einaudi, M.T., 2000. Porphyry gold deposits of the Refugio district, Maricunga belt, northern Chile. Econ. Geol. 95, $1445-1472$.

Muntean, J.L., Einaudi, M.T., 2001. Porphyry-epithermal transition: Maricunga belt, northern Chile. Econ. Geol. 96, 743-772.

Ohmoto, H., Lasaga, A.C., 1982. Kinetics of reactions between aqueous sulfates and sulfides in hydrothermal systems. Geochim. Cosmochim. Acta 46, 1727-1746.

Ozima, M., Podosek, F.A., 2002. Noble Gas Geochemistry. Cambridge Univ. Press, Cambridge, UK.

Petersen, E.U., Thompson, A.J.B., 1992. Analysis of alunite and other thermally sensitive minerals. Microprobe Analyst (Internal report, Dep. Geol. Geophys., Univ. Utah), April, pp. 2-6.

Pickthorn, W.J., O’Neil, J.R., 1985. ${ }^{18}$ O relations in alunite mineral: potential single mineral thermometer. Geol. Soc. Am. Abstr. Programs 17 (7), 686.

Poreda, R., Radicati di Brozolo, F., 1984. Neon in mid-Atlantic ridge basalts. Earth Planet. Sci. Lett. 69, 277-289.

Pouchou, J.L., Pichoir, F., 1985. PAP $(\rho Z)$ procedure for improved quantitative microanalysis. Microbeam Anal. 1985, 104-106.

Ramos, V.A., Mahlburg, K.S., Page, R.N., Munizaga, F., 1989. La ignimbrita Vacas Heladas y el cese del volcanismo en el Valle del Cura, Provincia de San Juan. Rev. Asoc. Geol. Argent. 44, $336-352$.

Reed, M.J.. 1995. Distribution of rare earth elements between aqueous fluids and granitic melt, $\mathrm{PhD}$ thesis, Univ. Maryland at College Park.

Rye, R.O., 1993. The evolution of magmatic fluids in the epithermal environment: the stable isotope perspective. Econ. Geol. 88, $733-753$.

Rye, R.O., 2005. A review of the stable-isotope geochemistry of sulfate minerals in selected igneous environments and related hydrothermal systems. Chem. Geol. 215, 5-36. (this volume).

Rye, R.O., Stoffregen, R.E., Bethke, P.M., 1990. Stable isotope systematics and magmatic hydrothermal processes in the 
Summitville, CO, gold deposit. U.S. Geol. Surv. Open-File, 90-626.

Rye, R.O., Bethke, P.M., Wasserman, M.D., 1992. The stable isotope geochemistry of acid sulfate alteration. Econ. Geol. 87, $225-262$.

Sandeman, H.A., Archibald, D.A., Grant, J.W., Villneuve, M.E., Ford, F.D., 1999. Characterisation of the chemical composition and ${ }^{40} \mathrm{Ar}-{ }^{39} \mathrm{Ar}$ systematics of intralaboratory standard MAC- 83 biotite. Radiogenic age and isotopic studies: report 12. Geol. Surv. Can. Current Res. 1999-F, 13-26.

Savin, S.M., Epstein, S., 1970. The oxygen and hydrogen isotope geochemistry of clay minerals. Geochim. Cosmochim. Acta 34, $24-42$.

Schoen, R., White, D., Hemley, J.J., 1974. Argillization by descending acid at steamboat springs, Nevada. Clays Clay Miner. 22, 1-22.

Schwab, R.G., Herold, H., Gotz, C., de Oliveira, N.P., 1990. Compounds of the crandallite type: synthesis and properties of pure rare earth element phosphates. Neues Jahrb. Mineral., $241-254$.

Seward, T.M., 1973. Thio complexes of gold and the transport of gold in hydrothermal ore solutions. Geochim. Cosmochim. Acta 37, 379-399.

Shepherd, T.J., Rankin, A.H., 1998. Fluid inclusion techniques of analysis. In: Richards, J.P., Larson, P.B. (Eds.), Techniques in Hydrothermal Ore Deposits Geology, Rev. Econ. Geol., vol. 10, pp. $125-150$.

Shinohara, H., 1994. Exsolution of immiscible vapor and liquid phases from a crystallizing silicate melt: Implications for chlorine and metal transport. Geochim. Cosmochim. Acta 58, 5215-5221.

Siddeley, G., Areneda, R., 1985. Gold-silver occurrences of the El Indio belt, Chile. In: Ericksen, G.E., Pinochet, M.T., Reinemund, J.A. (Eds.), Geology of the Andes and Its Relation to Hydrocarbon and Mineral Resources. CircumPacific Council for Energy and Mineral Resources, Earth Science Series, pp. 273-284.

Sillitoe, R.H., 1999. Styles of high sulfidation gold, silver and copper mineralization in the porphyry and epithermal environments. PACRIM '99 congress. Bali Indonesia, 10-13 October, Proc.-Australas. Inst. Min., pp. 29-44.

Steiger, R.H., Jäger, E., 1977. Subcommission on geochronology: convention on the use of decay constants in geo- and cosmochronology. Earth Planet. Sci. Lett. 36, 359-362.

Steven, T.A., Ratté, J.C., 1960. Geology of ore deposits of the Summitville district, San Juan Mountains, Colorado. U.S. Geol. Surv. Prof., 343.

Stoffregen, R.E., 1987. Genesis of acid-sulfate alteration and $\mathrm{Au}-$ $\mathrm{Cu}-\mathrm{Ag}$ mineralization at Summitville, Colorado. Econ. Geol. $82,1575-1591$.

Stoffregen, R.E., Alpers, C.N., 1987. Woodhouseite and svanbergite in hydrothermal ore deposits: products of apatite destruction during advanced argillic alteration. Can. Mineral. 25, 201-211.

Stoffregen, R.E., Cygan, G., 1990. An experimental study of Na-K exchange between alunite and aqueous sulfate solutions. Am. Mineral. 75, 209-220.
Stoffregen, R.E., Rye, R.O., Wasserman, M.D., 1994. Experimental studies of alunite: I. ${ }^{18} \mathrm{O}-16 \mathrm{O}$ and $\mathrm{D}-\mathrm{H}$ fractionation factors between alunite and water at $250-450{ }^{\circ} \mathrm{C}$. Geochim. Cosmochim. Acta 58, 903-916.

Taylor, B.E., 1986. Magmatic volatiles: isotopic variation of C, H, S.. In: Valley, J.W., Taylor Jr., H.P., O’Neil, J.R. (Eds.), Stable Isotopes in High Temperature Geological Processes, Rev. Mineral., vol. 16, pp. 185-225.

Taylor, B.E., 1988. Degassing of rhyolitic magmas: hydrogen isotope evidence and implications for magmatic-hydrothermal ore deposits. Can. Inst. Min. Metall. Spec. vol. 39, 33-49.

Taylor, B.E., 1991. Degassing of Obsidian Dome rhyolite, Inyo volcanic chain, California. In: Taylor Jr., H.P., O'Neil, J.R., Kaplan, I.R. (Eds.), Stable Isotope Geochemistry: A Tribute to Samuel Epstein, Geochem. Soc. Spec. Pub., vol. 3, 339-353.

Thompson, A.J.B., 1992. Alunite compositions and textures: relationships to precious metal mineralization. Mineral Deposit Research Unit Short Course \#8: New Developments in Lithogeochemistry. University of British Columbia, Vancouver, Canada.

Thompson, A.J.B., Hauff, P.L., Robitaille, A.J., 1999. Alteration mapping in exploration: Application of short-wave infrared (SWIR) spectroscopy. Soc. Econ. Geol. Newsl. 39, 13. (Oct.).

Truesdell, A.H., Nathenson, M., Rye, R.O., 1977. The effects of boiling and dilution on the isotopic compositions of Yellowstone thermal waters. J. Geophys. Res. 82, 3694-3704.

Ulrich, T., Gunther, D., Heinrich, C.A., 1999. Gold concentrations of magmatic brines and the metal budget of porphyry copper deposits. Nature 399, 676-679.

Venneman, T.W., Muntean, J.L., Kesler, S.E., O’Neil, J.R., Valley, J.W., Russell, N., 1993. Stable isotope evidence for magmatic fluids in the Pueblo Viejo epithermal acid sulfate $\mathrm{Au}-\mathrm{Ag}$ deposit, Dominican Republic. Econ. Geol. 88, 55-71.

Wasserman, M.D., Rye, R.O., Bethke, P.M., Arribas Jr., A., 1992. Methods for separation and total stable isotope analysis of alunite. U.S. Geol. Survey. Open-File Rep., 92-99.

Watanabe, Y., Hedenquist, J.W., 2001. Mineralogic and stable isotope zonation at surface over the El Salvador Porphyry Copper Deposit, Chile. Econ. Geol. 96, 1775-1798.

Williams, T.J., Candela, P.A., Piccoli, P.M., 1995. The partitioning of copper between silicate melts and two-phase aqueous fluids: an experimental investigation at $1 \mathrm{kbar}, 800{ }^{\circ} \mathrm{C}$ and $0.5 \mathrm{kbar}$, $850{ }^{\circ} \mathrm{C}$. Contrib. Mineral. Petrol. 121, 388-399.

Wood, S.A., 1990a. The aqueous geochemistry of the rare-earth elements and yttrium: 1 . Review of available low-temperature data for inorganic complexes and the inorganic REE speciation of natural waters. Chem. Geol. 82, 159-186.

Wood, S.A., 1990b. The aqueous geochemistry of the rare-earth elements and yttrium: 2 . Theoretical predictions of speciation in hydrothermal solutions to $350{ }^{\circ} \mathrm{C}$ at saturation water vapor pressure. Chem. Geol. 88, 99-125.

Zimbelman, D.R., Rye, R.O., Breit, G., 2005. Origin of secondary sulfate minerals on active andesitic stratovolcanoes. Chem. Geol. 215, 37-60. (this volume). 